\title{
Rola Prawosławnego Autokefalicznego Apostolskiego Kościoła Gruzińskiego w konfliktach na Kaukazie Południowym
}

Zarys treści: Artykuł ma za zadanie przybliżyć kwestie związane z obecnością chrześcijaństwa na terenach Gruzji oraz pokazać jak wielką rolę odgrywa Prawosławny Autokefaliczny Kościół Gruziński w dziejach narodu gruzińskiego. Tożsamość narodowa Gruzinów jest bowiem mocno związana z chrześcijaństwem i odrębnymi strukturami kościelnymi, co w istotny sposób wpływa na relacje ze społecznościami niegruzińskimi (Gruzja jest na Kaukazie Południowym krajem o największym odsetku mniejszości etnicznych), zamieszkującymi od pokoleń Gruzję i posługującymi się tamtejszym językiem, lecz traktowanymi jako „obce” ze względu na „niegruzińskie” wyznanie. Zapewnienie przez nowe władze (po odzyskaniu niepodległości przez Gruzję w 1991 r.) Prawosławnemu Autokefalicznemu Apostolskiemu Kościołowi Gruzińskiemu wyjątkowej roli w państwie poprzez stosowne ustawodawstwo przyczyniło się w dużym stopniu do wzrostu napięć społecznych i do zaognienia relacji z mniejszościami narodowymi i wyznaniowymi. Miało także swoje przełożenie na relacje Gruzji z najbliższymi sąsiadami. Te właśnie aspekty są szczegółowo omawiane przez autorkę w prezentowanym tekście. Autorka pokazuje, jak w wyniku specyficznych relacji, jakie wytworzyły się w Gruzji pomiędzy Kościołem a Państwem, religia poddana została instrumentalizacji i wykorzystana do osiągnięcia bieżących celów politycznych. Konkluzją jest stwierdzenie, że religia w Gruzji inspiruje podmioty nacjonalistyczne i wspiera nacjonalizm.

Outline of content: The article sheds light on the questions related to the presence of Christians in the Georgian territories and demonstrates the important role played by the Georgian Apostolic Autocephalous Orthodox Church in the history of the Georgian people. For the national identity of the Georgians is closely tied to Christianity and autonomous structures of the Church, which has a profound impact of relations with non-Georgian communities (in the Southern Caucasus Georgia has the largest percentage of ethnic minorities) inhabiting Georgia for centuries, speaking its language, but regarded as "alien" due to their "non-Georgian" religion. The fact that the new authorities provided the Georgian Apostolic Autocephalous Orthodox Church with an exceptional role in the state (after the country regained its independence in 1991) exacerbated ethnic, religious, and social conflicts in Georgia which translates into the 
relations of the country with its neighbours. Such are the questions examined by the author in the presented article. The author reveals how, under the conditions in Georgia which resulted from the specific relations between the Church and the State, religion was instrumentalised and used used to achieve immediate political aims. Her conclusion is that religion in Georgia inspires nationalist entities and supports nationalism.

Słowa kluczowe: Gruzja, Prawosławny Autokefaliczny Apostolski Kościół Gruziński, Katolikos (Patriarcha), konflikty religijne, konflikty etnoreligijne, konflikty społeczne, mniejszości narodowe, mniejszości religijne, mniejszości seksualne, relacje Kościół-państwo

Keywords: Georgia, Georgian Apostolic Autocephalous Orthodox Church, Catholicos (Patriarch), religious conflicts, ethno-religious conflicts, social conflicts, minorities, religious minorities, sexual minorities, Church-State relations

Dwudziesty pierwszy wiek zwrócił uwagę na religię jako czynnik wyjaśniający stosunki międzynarodowe i mechanizmy funkcjonowania świata i polityki. Do tej pory w naukach społecznych ignorowano tę rolę religii - przyczyną tego był fakt, że w badaniach koncentrowano się głównie na krajach Zachodu, gdzie wpływy religijne były najmniejsze ${ }^{1}$. Błędnie też uważano, że wraz z postępującą modernizacją (rozumianą jako westernizacja) wpływy religijne w innych częściach świata będą słabnąć. Tymczasem jednym z następstw procesów modernizacyjnych było odrodzenie się religii (jak również sięgnięcie do legitymacji religijnej) ${ }^{2}$. W niemałej części świata demokracja stanowi zamach na systemy społeczne oparte na zasadach religijnych. Jak słusznie podkreśla Georges Corm, w momencie, kiedy religia zaczęła tracić swój transcendentalny charakter i zaczęła być wykorzystywana do celów politycznych przez kierujące społeczeństwami systemy władzy, wielu wiernych - w tym także polityków nieakceptujących takiej sytuacji - głosiło potrzebę powrotu do źródeł, zwrócenia się do korzeni. Stwarzało to sytuację, w której łatwo było pomylić tożsamość religijną z tożsamością narodowościową. Odwoływanie się do religii miało również stać się lekarstwem na głębokie rozczarowanie polityką, a także remedium na dewaluujący się system kształtowania nowoczesnej tożsamości narodowej, wznoszącej się ponad etniczność i specyfikę religijną ${ }^{3}$. Według niektórych teorii istnieje coraz silniejszy związek między religią a konfliktami wewnętrznymi i zewnętrznymi. Coraz częściej dochodzi do zjawiska „polityzacji religii” - religia zaczyna pełnić funkcje integracyjne, mobilizujące, wychowawcze, a w efekcie także polityczne $e^{4}$.

1 Zwrócili na to uwagę J. Fox i S. Sandler, Bringing Religion into International Relations, New York 2004.

2 M. Marczewska-Rytko, Religia i polityka w globalizującym się świecie, Lublin 2010, s. 80-86.

${ }^{3}$ G. Corm, Religia i polityka w XXI wieku, tłum. E. Cylwik, Warszawa 2007, s. 86.

4 A. Legucka, Geopolityczne uwarunkowania i konsekwencje konfliktów zbrojnych na obszarze poradzieckim, Warszawa 2013, s. 108. 
Przedmiotem poniższych rozważań będzie oddziaływanie czynnika religijnego na zmiany dokonujące się w Republice Gruzji po 1991 r. Analizowany będzie on zarówno jako generator konfliktów (etnicznych, społecznych, międzynarodowych), jak i łagodzący, lub rozwiązujący konflikt. Ponieważ w literaturze przedmiotu jest stosunkowo dużo prac ujmujących to zagadnienie w sposób teoretyczny, poniższy tekst będzie studium przypadku${ }^{5}$. Autorka postara się prześledzić, w jaki sposób w Gruzji różni aktorzy o charakterze religijnym mogą wpływać pośrednio i bezpośrednio na wewnętrzną politykę państwa i w jakim stopniu ma to znaczenie dla kształtowania się stosunków międzynarodowych. Przedmiotem zainteresowania będzie prześledzenie relacji pomiędzy stanowiskiem (udzielenie wsparcia lub jego brak) autorytetu religijnego jakim jest katolikos Ilia II wobec konkretnych konfliktów, i w jakim stopniu staje się to czynnikiem prowadzącym do wybuchu lub zakończenia konfliktu.

Gruzja jest od ponad 16 wieków krajem ortodoksyjnie chrześcijańskimi ${ }^{6}$. Kościół Gruziński ${ }^{7}$ od średniowiecza rozwijał szczególne poczucie odrębności religijnej zarówno wobec świata islamu, jak i prawosławnego - poprzez język, własną tradycję także w architekturze i śpiewie kościelnym) oraz szereg mitów narodowo-religijnych ${ }^{8}$. Tożsamość narodowa Gruzinów jest mocno związana z chrześcijaństwem i odrębnymi strukturami kościelnymi9. Kościół Gruziński przez wiele wieków był silną instytucją o charakterze narodowym, która zwłaszcza po utracie państwowości przez Gruzję, spełniała, równolegle do posługi religijnej, konkretne funkcje polityczno-społeczne: kultywowała pamięć narodową, stała na straży rodzimej tradycji, kultury. Długa tradycja autokefalii i wynikające $z$ autonomicznego rozwoju różnice wytworzyły specyficzne poczucie przywiązania do Kościoła,

5 T. Szyszlak, Próby teoretycznego ujęcia postradzieckich konfliktów religijnych, w: Religia i polityka na obszarze Europy Wschodniej, Kaukazu i Azji Centralnej, red. T. Stępniewski, Lublin-Warszawa 2013, s. 49-64; S. Matiunin, Konflikty religijne na terenie byłego ZSRR, w: Religie i kościoły w społeczeństwach postkomunistycznych, red. I. Borowik, A. Szyjewski, Kraków 1993, s. 204-209; Религия и конфликт, ред. А. Малашенко, С. Филатов, Москва 2007.

${ }^{6}$ We wschodniej części Gruzji - Iberii - chrześcijaństwo zostało uznane za religię panującą w 337 r., a autokefalię przyjęto w $483 \mathrm{r}$. W zachodniej części - Lazyce - doszło do tego dopiero w $523 \mathrm{r}$. D. Zadura, Chrześcijaństwo i Kościół narodowy w historii Gruzji - od źródeł do okresu sowieckiego, „Pro Georgia. Journal of Kartvelological studies” 19 (2009), s. 134-136. Zob. też: G. Peradze, Problemy historii początków Kościoła Gruzińskiego, w: idem, Dzieła zebrane, t. 2, red. ks. H. Paprocki, Warszawa 2011, s. 7-25; R.G. Suny, The Making of Georgian Nation, Bloomington 1994, s. 20-41.

7 Oficjalna nazwa brzmi: Prawosławny Autokefaliczny Apostolski Kościół Gruziński. W pracy autorka będzie używać terminu „Kościół Gruziński” (kartluli eklesia).

${ }^{8}$ Kościół Gruziński został zjednoczony w XII w., kiedy to patriarcha Antiochii uznał roszczenia jurysdykcji Katolikosa Mcchety do całego terytorium gruzińskojęzycznego. Wynikiem zjednoczenia struktur kościelnych Gruzji wschodniej i zachodniej było przyjęcie przez patriarchów Mcchety tytulatury Katolikos - Patriarcha całej Gruzji; D. Zadura, op. cit., s. 133, 141.

9 Znaczenie religii jako czynnika wpływającego na kształtowanie się narodu gruzińskiego było świadomie pomijane w literaturze i historiografii radzieckiej. 
któremu Gruzini dawali wyraz, sprzeciwiając się podporządkowaniu go czy to Cerkwi Rosyjskiej, Imperium Rosyjskiemu, czy władzy sowieckiej ${ }^{10}$.

W wyniku prowadzonej przez Rosję polityki na terenach gruzińskich (likwidacja w 1811 r. autokefalii Kościoła Gruzińskiego i brak poszanowania dla tradycji gruzińskich) miejsce początkowej sympatii dla Rosji, opartej na wspólnocie wyznaniowej (dla której Gruzini nie poparli górali kaukaskich w walce z Rosjanami) i szukaniu sojusznika w walce z Turkami, zaczęła zajmować niechęć i wrogośćl1. Po zniesieniu namiestnictwa kaukaskiego w 1882 r. i zaostrzeniu polityki rusyfikacji wobec Gruzinów - w szczególności walki z językiem - władze starały się wzmocnić na terenach Gruzji rosyjską grupę etniczną. Gruzinów osiedlano na miejsce wysiedlanych z wybrzeży Morza Czarnego muzułmanów, a także popierano mniejszości etniczne zamieszkujące ziemie gruzińskie - w tym szczególnie Osetyńców. Cesarstwo Rosyjskie skłócało również plemiona gruzińskie, wykorzystując różnice między językami gruzińskim i megrelskim - stworzenie nowego alfabetu języka megrelskiego, promowanie go, utwierdzanie Megrelów w przekonaniu o ich odrębności w stosunku do innych plemion gruzińskich ${ }^{12}$.

Gruzja jest krajem, w którym wewnętrzne różnice etnograficzne ${ }^{13}$ są silnie widoczne do dnia dzisiejszego. Większość różnic wynika z przyczyn historycznych i sięga czasów istnienia plemion gruzińskich (m.in. Kartwelów, Megrelów i Swanów) zjednoczonych jeszcze przed naszą erą. Istnienie przez długi okres czasu dwóch państw gruzińskich - wschodniego (Iberia) i zachodniego (Kolchida), dwa kierunki przyjścia chrześcijaństwa (do zachodniego królestwa z Bizancjum, a do wschodniego z Syrii i Palestyny) oraz istnienie dwóch stref oddziaływania potężnych sąsiadów (w zachodniej części - Grecji, Bizancjum, Imperium Osmańskiego, we wschodniej zaś Persji), wszystko to wpływało na utrwalenie różnic etnograficznych ${ }^{14}$. W Gruzji mozaikę narodowościową dopełniają podziały religijne. Niejednorodność religijna w obrębie jednej grupy etnicznej jest wynikiem burzliwej historii. Wojny i wydarzenia polityczne powodowały fale emigracji ludności zasiedziałej i napływ przesiedleńców z innych terenów.

Wskutek zawirowań dziejowych doszło do wytworzenia się skomplikowanej sytuacji etnicznej i wyznaniowej na ziemiach gruzińskich. Obecnie Gruzja jest na Kaukazie Południowym krajem o największym odsetku mniejszości etnicznych.

10 D. Zadura, Naród w tygrysiej skórze. Tożsamość narodowa Gruzinów w dobie „rewolucji róż”, w: Dylematy kaukaskie. Problemy narodowościowe i migracyjne, red. M. Ząbek, Warszawa 2010, s. 286-287.

${ }^{11}$ N. Sabanadze, Globalization and nacionalism: the cases of Georgia and the Basque country, Budapest-New York 2010, http://books.openedition.org/ceup/573, [punkt 20] (dostęp: 1.07.2015).

12 A. Furier, Droga Gruzji do niepodległości, Poznań 2009, s. 61.

13 Grupy etnograficzne wyróżniane są na podstawie odrębnych, obiektywnych cech kulturowych, choć nie zawsze świadomości odrębności grupowej. Stanowią zazwyczaj część grup i wspólnot etnicznych lub występują na ich pograniczu. Zob: D. Zadura, Naród w tygrysiej skórze..., s. 291.

${ }^{14}$ Ibidem, s. 291-292. 
Ponad 80\% obywateli stanowią etniczni Gruzini, z których zdecydowana większość (83\%) przynależy do Kościoła Gruzińskiego. Blisko 10 \% mieszkańców Gruzji wyznaje islam $^{15}$, a około 6\% jest wiernymi Apostolskiego Kościoła Ormiańskiego. Oprócz prawosławia, islamu i wyznania ormiańskiego do tzw. religii tradycyjnych Gruzji zalicza się również katolicyzm (około 35 tys. wiernych) i judaizm (około 10 tys. wiernych). Liczbę Jezydów zamieszkujących w Gruzji ocenia się na 18 tys. Trudne do oszacowania wspólnoty protestanckie nie przekraczają $1 \%{ }^{16}$.

W okresie radzieckim Kościół Gruziński doświadczył podobnych represji jak inne kościoły - w pierwszej kolejności odebrano mu majątek, a następnie rozpoczęto zamykanie świątyń i prześladowanie duchownych oraz wiernych ${ }^{17}$. Represje stalinowskie wymierzone były w ogóle w religie, w związku z czym ich ofiarą padały też inne kościoły. Osławiona wrogość komunistów do religii miała_uzasadnienie nie tylko doktrynalne, ideologiczne, ale także pragmatyczne. Kościół był postrzegany w kategoriach quasi-politycznej siły, konkurencyjnej wobec oficjalnego, państwowego ośrodka władzy, a jego istnienie skutecznie uniemożliwiało monopolizację i centralizację władzy przez komunistów ${ }^{18}$. Represje, jakich doświadczył Kościół Gruziński, spowodowały, że Święty Synod Kościoła Gruzińskiego zadecydował w 1927 r., że aby przetrwać, trzeba pójść na współpracę z nowymi władzami i zachować wobec nich lojalność ${ }^{19}$.

Kościół Gruziński swoją kulturową rolę w historii Gruzji zaczął podkreślać z całą mocą w czasie odwilży związanej z pierestrojką Gorbaczowa. Formą manifestacji tożsamości narodowej stało się w tym czasie stawanie w obronie Kościoła Gruzińskiego. Na masowych demonstracjach wykorzystywano jako symbol znienawidzone i zakazane przez władze krzyże i ikony ${ }^{20}$. Niezwykle silne zaakcentowanie roli Kościoła narodowego było protestem przeciwko ateistycznemu komunizmowi i prześladowaniom, jakich zarówno Kościól, jak i naród gruziński doznał od Imperium Rosyjskiego i Związku Socjalistycznych Republik Radzieckich

${ }^{15}$ Są to przede wszystkim Azerowie, mieszkańcy Adżarii, Czeczeńcy, część Abchazów, Tatarzy i Awarzy.

16 G. Rtskhiladze, Religion and Conflict Potential in Georgia, "Central Asia and the Caucasus” 3 (39) (2005), s. 56. Dane te w następnych latach nie uległy większej zmianie, zob. Georgia 2013 International Religious Freedom Report, Department of State USA, www.state.gov/documents/ organization/222429.pdf (dostęp: 15.07.2015).

17 Szerzej na ten temat zob. G. Peradze, Kościót Gruziński pod bolszewizmem, w: idem, Dzieła zebrane..., s. 285-288; T.T. Chmielowski, Kościół Prawosławny w Gruzji w latach zaboru rosyjskiego i władzy sowieckiej (XIX-XX w.), „Archiwa, Biblioteki i Muzea Kościelne” 70 (1998), s. 303-313.

18 R. Zenderowski, Religia a tożsamość narodowa i nacjonalizm w Europie Środkowo-Wschodniej. Między etnicyzacja religii a sakralizacja etnosu (narodu), Wrocław 2011, s. 80-81.

19 D. Zadura, Chrześcijaństwo i Kościół narodowy..., s. 153.

${ }^{20}$ Katolikos m.in. bezskutecznie przekonywał ludzi do rozejścia się 9 kwietnia 1989 r., kiedy wojska Zakaukaskiego Okręgu Wojskowego dokonały masakry demonstrantów zgromadzonych w alei Rustawelego w Tbilisi. W. Materski, Gruzja, Warszawa 2010, s. 258. 
(ZSRR) ${ }^{21}$. Działania Kościoła Gruzińskiego wpisują się w zauważalne prawidłowości czasu transformacji ustrojowych po upadku komunizmu. Procesem występującym w większości państw, które odzyskały niepodległość, jest wykorzystywanie przez lokalne kościoły, w większości cerkwie prawosławne, okazji do wypełnienia pustki ideologicznej po komunizmie, a tym samym wzmocnienie swojej obecności w przestrzeni publicznej, z której przez dziesięciolecia były wypychane ${ }^{22}$. Zgłaszają one również pod adresem państwa żądania dotyczące uznania ich za dominujące na danym terytorium, $\mathrm{z}$ jednoczesnym prawnym ograniczeniem praw wyznawców innych religii, uniemożliwiającym w praktyce ich rozwój instytucjonalny ${ }^{23}$.

Gruzini zadbali o to, aby w najważniejszym akcie prawnym ich Kościołowi przyznana została wyjątkowa rola w państwie. Uchwalona przez parlament 24 sierpnia 1995 r. konstytucja Gruzji w art. 14 gwarantuje wszystkim obywatelom wolność i równość wobec prawa, niezależnie m.in. od religii, przynależności narodowej, etnicznej i społecznej oraz przekonan. Powtarza to art. 38, ust. 1 („Obywatele Gruzji są równi w życiu społecznym, gospodarczym, kulturowym i politycznym, niezależnie od ich przynależności narodowej, etnicznej, religijnej lub językowej”), a art. 19, ust.1 doprecyzowuje te postanowienia, zapewniając każdemu wolność słowa, poglądów, wyznania i przekonań, pod warunkiem, że nie naruszają one praw i wolności innych osób ${ }^{24}$. Co więcej, ust. 2 wymienionego wyżej artykułu zakazuje jakichkolwiek przejawów nienawiści religijnej, zaś ust. 3 zawiera regulacje zakazującą jakiegokolwiek ograniczenia prawa do wolności religijnej ${ }^{25}$. Niestety, zapisy te długo pozostawały tylko martwą literą ${ }^{26}$.

W wyniku zażartych walk w parlamencie Kościołowi Gruzińskiemu została przyznana wyjątkowa rola $w$ państwie, co znalazło odzwierciedlenie w art. 9, ust. 1 konstytucji: „Państwo deklaruje pełną wolność wyznania i religii, jak również uznaje szczególną rolę Prawosławnego Autokefalicznego Apostolskiego Kościoła Gruzińskiego w historii Gruzji i jego niezawisłość od państwa"27. W ten sposób

${ }^{21}$ R. Król-Mazur, Polityczne aspekty działalności Prawosławnego Autokefalicznego Apostolskiego Kościoła Gruzińskiego po 1991 r., w: Na wschód od linii Curzona. Księga Jubileuszowa dedykowana profesorowi Mieczysławowi Smoleniowi, red. R. Król-Mazur, M. Lubina, Kraków 2014, s. 281; zob. też. A. Furier, Znaczenie relacji między Kościołem a władzami państwowymi dla kształtowania się państwa i narodu gruzińskiego, w: Etniczność a religia, red. A. Posern-Zieliński, Poznań 2003, s. 155.

22 R. Zenderowski, op. cit., s. 93-94.

${ }^{23}$ Ibidem, s. 95.

24 The Constitution of the Republic of Georgia, Parliament of Georgia, http:// www.parliament.ge/ files/68_1944_951190_CONSTIT_27_12.06.pdf (dostęp: 18.11.2014); G. Kuca, M. Grzybowski, System konstytucyjny Gruzji, Warszawa 2012, s. 25.

25 The Constitution of the Republic of Georgia...

${ }^{26}$ W celu obrony i poszanowania praw człowieka Gruzja przyjęła 15 wrzesnia 1991 r. Deklarację Praw Człowieka, przyjmując tym samym na siebie obowiązek poszanowania i obrony prawa do wolności, nałożony przez Organizacje Narodów Zjednoczonych.

27 The Constitution of the Republic of Georgia... 
Gruzja obok Armenii stała się drugim państwem, w którym odstąpiono od zasady rozdziału Kościoła od państwa ${ }^{28}$.

Ponieważ w konstytucji znalazła się równocześnie gwarancja wolności innych religii, 30 marca 2001 r. dopisano do 9 art. ust. 2, w którym stwierdzono, że stosunki między państwem a Kościołem Gruzińskim ureguluje umowa konstytucyjna. Została ona podpisana 14 października 2002 r. w katedrze Sweti Cchoweli w Mcchecie przez Ilię II i Eduarda Szewardnadzego, a następnie 22 października ratyfikowana przez parlament i Święty Synod, mimo sprzeciwu gruzińskich prawników oraz specjalistów z Parlamentu Europejskiego. Jej zawarcie uzasadniono głównie względami historycznymi - faktem bycia religią państwową i jej wpływem na formowanie kultury, światopoglądu i wartości narodowych ${ }^{29}$. Umowa składa się z 12 artykułów poprzedzonych preambułą ${ }^{30}$. Jako część konstytucji jest nadrzędna wobec innych aktów prawnych i stanowi uznanie dla rangi Kościoła Gruzińskiego. Uznaje osobowość prawną Kościoła Gruzińskiego, jego instytucję oraz nienaruszalność Katolikosa - Patriarchy Całej Gruzji (art. 1, ust. 3, 4, 5). Reguluje też kwestie m.in. świąt, związków małżeńskich, spowiedzi, kapelanów, edukacji religijnej (Kościół Gruziński ma wyłączne prawo do układania programów nauczania religii oraz wyznaczania wykładowców ${ }^{31}$ ), własności i finansowania Kościoła ${ }^{32}$. Na mocy Umowy Kościół Gruziński został zwolniony z płacenia podatku od nieruchomości, a osobie pełniącej godność katolikosa przysługuje immunitet karny. Rząd zobowiązał się do zwrotu Kościołowi Gruzińskiemu wszystkich ziem i dóbr ruchomych skonfiskowanych po $1917 \mathrm{r}^{33}$, także tych znajdujących się obecnie $\mathrm{w}$ narodowych zbiorach muzealnych. Obiecano również wypłacić odszkodowania za lata prześladowań oraz wesprzeć budowę seminariów dla duchownych, którzy mają pełnić posługę w wojsku i więzieniach. Kościołowi Gruzińskiemu przyznano decydujący głos w kwestii sprowadzania do Gruzji nieprawosławnej literatury

${ }^{28}$ Zob. też T.J. Szyszlak, Wolność religijna w konstytucjach i ustawach wyznaniowych państw postradzieckich, „Studia z Prawa Wyznaniowego” 10 (2007), s. 242-243.

29 T.J. Szyszlak, Stosunki państwa $z$ Apostolskim Autokefalicznym Kościołem Prawosławnym we współczesnej Gruzji, w: Badania wschodnie. Polityka wewnętrzna i międzynarodowa, red. W. Baluk, Z.J. Winnicki, Wrocław 2008, s. 80.

30 Zob. Porozumienie Konstytucyjne między Państwem Gruzińskim i Gruzińskim Apostolskim Autokefalicznym Kościołem Prawosławnym z 14 X 2002, tłum. T. Szyszlak, w: ibidem, s. 361-364.

31 Oświata w państwach postradzieckich ma w większości przypadków świecki charakter.

32 Porozumienie Konstytucyjne między Państwem Gruzińskim..., s. 361-364; The Political Landscape of Georgia. Political Parties: Achievements, Challenges and Prospects, eds. G. Nodia, Á. Pinto Scholtbach, Delft 2006, s. 69-71; P. Nieczuja-Ostrowski, Religia w polityce w państwach Kaukazu Południowego, w: Religia i polityka na obszarze Europy Wschodniej, Kaukazu i Azji Centralnej, red. T. Stępniewski, Lublin-Warszawa 2013, s. 298; L. Kończak, Religia i konflikty religijne w niepodległej Gruzji, w: Konflikty na obszarze byłego ZSRR, red. P. Adamczewski, Poznań 2009, s. 167-168.

33 A. Curanović, Religie, Kościoły i konflikty międzywyznaniowe w regionie Kaukazu, w: Wprowadzenie do Studiów Wschodnioeuropejskich, t. 4: Armenia, Azerbejdżan, Gruzja - przeszłość i teraźniejszość, red. M. Korzeniowski, D. Tarasiuk, K. Latawiec, Lublin 2013, s. 201. 
religijnej i wznoszenia nowych obiektów religijnych - co w praktyce oznacza podporządkowanie mu innych związków wyznaniowych ${ }^{34}$.

Kościół Gruziński uzyskał także inne przywileje zapisane w umowie konstytucyjnej i innych aktach prawnych. Wprowadzono utrudnienia w rejestracji związków religijnych i grup wyznaniowych oraz w wydawaniu zgody na budowę świątyń przez inne wyznania. Kościołowi Gruzińskiemu przekazano budynki i kościoły należące wcześniej do katolików (Gori, Kutaisi, Batumi). Uzyskał on też ulgi podatkowe, dotacje $\mathrm{z}$ budżetu centralnego i możliwość uzyskania dotacji z budżetów samorządowych, a także prawo do otwierania własnych szkół. Kościół Gruziński cały czas czyni starania o wzmocnienie swojej pozycji, wykorzystując do tego zapisy konstytucyjne ${ }^{35}$. W 1999 r. pojawiły się też głosy, by proklamować prawosławie religią państwową - hasło takie lansował lider ruchu „Nasza Gruzja”, Guram Szaradze ${ }^{36}$. W 2006 r. 65\% społeczeństwa gruzińskiego wyraziło taką wolę 37 .

Według opublikowanego na początku 2015 roku raportu Win/Gallup International Association Gruzja znalazła się w dziesiątce najbardziej religijnych państw na świecie ${ }^{38}$. Jednak w rzeczywistości Gruzini niewiele wiedzą o swojej religii, choć coraz bardziej aktywnie uczestniczą w rytuałach i obrzędach. $\mathrm{W}$ dużym stopniu motywuje ich potrzeba określenia własnej przynależności do konkretnej wspólnoty.

Odzyskujący wolność Gruzini hasła nacjonalistyczne połączyli z wyznawaniem prawosławia, a prawdziwym Gruzinem był tylko ten, kto należał do Kościoła Gruzińskiego. W sensie ideologicznym wykluczono z narodu Gruzinów, którzy byli katolikami, muzułmanami czy ateistami. W wyniku tego Kościół Gruziński przez dłuższy czas był jedynym, który mógł w Gruzji funkcjonować, co stanowiło zaprzeczenie jej wielowiekowej tradycji ${ }^{39}$. Wyznawców religii tradycyjnie zakorzenionych w Gruzji nie uważa się za Gruzinów ${ }^{40}$. Eskalacja nacjonalizmu była w pewnym sensie reakcją na kolonizację i rusyfikację. Kościół Gruziński musiał się odnaleźć w nowej sytuacji, bowiem po upadku ZSRR możliwe stało się też funkcjonowanie w Gruzji zwalczanych dotąd przez władze radzieckie sekt. Mogły także zacząć działać inne kościoły i związki wyznaniowe. Pojawienie się ich było odbierane

${ }^{34}$ Porozumienie Konstytucyjne między Państwem Gruzińskim..., s. 361-364; A. Curanović, Rosyjsko-kaukaskie sąsiedztwo w kontekście stosunków międzywyznaniowych, w: Kaukaz w stosunkach międzynarodowych. Przeszłość, teraźniejszość, przyszłość, red. P. Olszewski, K. Borkowski, Piotrków Trybunalski 2008, s. 381-382.

35 A. Curanović, Rosyjsko-kaukaskie sasiedztwo..., s. 381-382; L. Kończak, op. cit., s. 167-168, 171.

${ }^{36}$ Został on zastrzelony w 2007 r. w Tbilisi na ulicy, T.J. Szyszlak, Stosunki państwa z Apostolskim..., s. 83; L. Kończak, op. cit., s. 165.

37 A. Szabaciuk, Między konfliktem a pokojem. Polityka etniczna i wyznaniowa Gruzji w latach 1991-2012, „Wschodnioznawstwo” 2012, s. 68.

38 Грузия вошла в десятку самых религиозных стран, Православие. Ru. 14.04.2015, http://www. pravoslavie.ru/news/78649.htm (dostęp: 15.12.2015).

39 L. Kończak, op. cit., s. 164.

40 G. Rtskhiladze, op. cit., s. 56. 
jako przejaw globalizacji ${ }^{41}$. Postępujące zmiany, do których doszło w tym okresie, doprowadziły do nałożenia się na siebie dwóch ekstremizmów - religijnego i narodowego. Nacjonalizm wciągnął w swoją orbitę prawosławie, a obywatele Gruzji niejednokrotnie mogli usłyszeć: „Ty nie jesteś Gruzinem, ale jakimś Ormianinem, Polakiem, Rosjaninem, albo jeszcze kimś innym"42. Efektem takiego nastawienia były liczne akty przemocy (przy bierności policji i władz) dokonywane przez radykalnych członków Kościoła Gruzińskiego na przedstawicielach innych grup wyznaniowych (zwłaszcza na świadkach Jehowy i krysznowcach, baptystach czy zielonoświątkowcach). Szczególnie w latach 1998-2003 dochodziło do częstych napadów na ich świątynie, do pogromów i do niszczenia literatury. Ze strony prawosławnych radykałów podnoszone były żądania wypędzenia „sekt”43 oraz ograniczenia wolności religijnej ${ }^{44}$. Dochodziło do wypadków publicznego palenia niewygodnej literatury religijnej oraz niszczenia i grabieży biur organizacji pozarządowych zajmujących się ochroną praw człowieka ${ }^{45}$. W tym czasie miały miejsce gorące debaty publiczne na temat obcych wpływów kulturowych i religijnych i roli prawosławia w zachowaniu tożsamości narodowej Gruzinów. G. Szaradze oskarżył ambasadora USA w Gruzji, Richarda Miles’a, oraz innych członków społeczności międzynarodowej o popieranie „sekt”, a tym samym o działania antygruzińskie, stwierdzając, że obowiązkiem Gruzinów jest bronić się przed zagrożeniem, jakie dla ich narodu i tradycji stanowią obce grupy religijne ${ }^{46}$. W końcu sierpnia 2002 roku rzecznik prasowy Kościoła Gruzińskiego, Zgrab Cchowrebadze, stwierdził, że w walce z sektami oprócz patriarchatu gruzińskiego powinno brać udział całe kierownictwo kraju i całe społeczeństwo. Określił on sekty mianem "piątej kolumny”, którą należy rozbroić, ale bez używania przemocy ${ }^{47}$. Według danych zawartych w Międzynarodowym Raporcie Wolności Religijnej za 2013 r.,

${ }^{41} \mathrm{~W}$ warunkach globalizacji, dzięki środkom masowego komunikowania i wielkich ruchów migracyjnych coraz lepiej można poznać inne religie, a społeczeństwa stają się multireligijne. Ta konfrontacja miedzy obcymi kulturami, religiami powoduje, że w niektórych krajach - w tym przypadku również w Gruzji - mamy do czynienia $\mathrm{z}$ tzw. kulturową obroną. W przypadku Gruzji religia (której reprezentantem jest Prawosławny Autokefaliczny Apostolski Kościół Gruziński) jest na stałe wpisana w historię i kulturę tego narodu. Na temat stosunku Kościołów do globalizacji zob. intersujący tekst J. Mariańskiego, Globalizacja i Kościoły - sprzymierzeńcy czy konkurenci, w: Religia i religijność w warunkach globalizacji, red. M. Libiszowska-Żółtkowska, Kraków 2007, s. 105-126.

42 Gruzin nie może być katolikiem, „Niedziela” 11.06.2008, www.niedziela.pl/wiad.php?p=200806\&idw $=149$ (dostęp: 4.08.2015).

${ }^{43}$ O prozelityzmie uprawianym w Gruzji przez różne „destrukcyjne” sekty wspominał na spotkaniu z mniejszością ormiańską w Krakowie 25.03.2013 r. abp Rafael Minassian, zwierzchnik Ormian-katolików w Europie Wschodniej.

44 The Political Landscape of Georgia..., s. 71-72; D. Zadura, Naród w tygrysiej skórze..., s. 285.

45 T.J. Szyszlak, Stosunki państwa z Apostolskim..., s. 83.

${ }^{46}$ N. Sabanadze, Globalization and nationalism: the cases of Georgia and the Basque country, Budapest-New York 2010 http://books.openedition.org/ceup/573 [punkt 79] (dostęp: 1.07.2015).

47 T.J. Szyszlak, Stosunki państwa z Apostolskim..., s. 83-84. 
opublikowanym przez Departament Stanu USA (biuro ds. demokracji, praw człowieka i pracy) wynika, iż pomimo prześladowań jakich doznawały „nietradycyjne grupy religijne" w Gruzji - takie jak świadkowie Jehowy, baptyści, zielonoświątkowcy, krysznowcy - ciągle rośnie ich liczba ${ }^{48}$.

Na początku lutego 2002 r. przedstawiciele gruzińskich katolików, judaistów, muzułmanów, luteranów i baptystów wystosowali list otwarty do prezydenta Gruzji Eduarda Szewardnadzego z prośbą o użycie niezbędnych środków przeciw przemocy na gruncie religijnym. Pół roku później 15 kongresmenów amerykańskich zaproponowało prezydentowi Gruzji użycie skutecznych środków w tym kierunku ${ }^{49}$.

W przypadku dużych wyznań - takich jak katolicy, muzułmanie czy wyznawcy Apostolskiego Kościoła Ormiańskiego - nie ma wprawdzie problemu, żeby pójść do kościoła i wziąć udział w nabożeństwie, ale poważnym problemem jest już funkcjonowanie w życiu społecznym (szkoła, uczelnia, praca) ${ }^{50}$. Sytuacja mniejszości etnicznych i religijnych była negatywnie oceniana przez Radę Europy i jej Komitet Doradczy ds. Ramowej Konwencji o Ochronie Mniejszości Narodowych ${ }^{51}$. W krytycznym raporcie z 12 października 2009 r. uznano, że sytuacja mniejszości etnicznych i religijnych $w$ tym kraju jest jednym $\mathrm{z}$ najpoważniejszych problemów wewnętrznych. Zwrócono uwagę na wzrastające napięcia na tle religijnym, wynikające $\mathrm{z}$ faworyzowania przez władze Kościoła Gruzińskiego i niemożności zarejestrowania się przez inne związki wyznaniowe ${ }^{52}$.

Gruzińscy adwokaci walczący o prawa człowieka zwracają uwagę, że chrześcijańsko-nacjonalistyczne ugrupowania są również wrogo nastawione do Żydów, co w przyszłości może przyczynić się do wybuchu kolejnych konfliktów ${ }^{53}$. Akty antysemityzmu są coraz częstsze - np. 4 grudnia 2013 r. w Tbilisi miały miejsce protesty przeciwko obchodom święta Chanuka i udziałowi w nich prezydenta Giorgia Margwelaszwilego, w czasie których pod adresem prezydenta padały okrzyki „Żyd”. Dwaj najwięksi prowodyrzy zostali aresztowani i ukarani grzywną w wysokości 100 lari. W ich intencji odbyła się msza święta zorganizowana pod ambasadą

48 Georgia 2013 International Religious Freedom Report, Department of State USA, www.state.gov/ documents/organization/222429.pdf (dostęp: 15.07.2015).

49 T.J. Szyszlak, Stosunki państwa z Apostolskim..., s. 85.

${ }^{50}$ Gruzin nie może być katolikiem...

${ }^{51}$ W 2005 roku Gruzja ratyfikowała Konwencję Ramową Rady Europy o Ochronie Mniejszości Narodowych i rozpoczęła szeroki okres współpracy z Wysokim Komisarzem OBWE w celu zabezpieczania praw mniejszości i wspieranie ich integracji w ramach głównego nurtu społeczeństwa gruzińskiego, N. Sabanadze, Globalization and nationalism: the cases of Georgia and the Basque country, Budapest-New York 2010, http://books.openedition.org/ceup/573 [punkt 88] (dostęp: 1.07.2015).

52 Rada Europy o problemach mniejszości etnicznych i religijnych w Gruzji, Ośrodek Studiów Wschodnich, 12.10.2009, http://www.osw.waw.pl/pl//publikacje/tydzień-na-wschodzie/2009-10-12/radaeuropy-o-problemach-mniejszosci-etnicznych-i-religijnych-w-Gruzji (dostęp: 13.04.2015).

${ }^{53}$ Dyskryminacja ateistów w Gruzji. Wplywy Cerkwi w interesie Rosji 21.07.2015 http://onet.tv/i/ dowiedzsie/dyskryminacja-ateistow-w-gruzji-wplywy-cerkwi-w-interesie-rosji/3zdzlh (dostęp: 22.07.2015). 
Izraela przez grupę księży Kościoła Gruzińskiego. Sam katolikos skomentował te wydarzenia wprawdzie jako „nie do przyjęcia”, ale zarazem potwierdził prawo do wolności słowa ${ }^{54}$.

O wiele gorsza jest w tym kraju sytuacja ateistów, którzy doświadczają prześladowań na każdym kroku. Zdarzają się sytuacje pobicia niewierzących uczniów przez kolegów, na które szkoła ze względu na coraz silniejsze wpływy ugrupowań chrześcijańsko-fundamentalistycznych nie reaguje ${ }^{55}$.

W Gruzji religia pełni ważną rolę w socjalizacji dzieci ${ }^{56}$. Rozwijając poczucie przynależności religijnej, zaczynają one postrzegać innych (członków innego Kościoła, ateistów) jako wrogów, czy jako ludzi gorszych od członków własnej grupy - Gruzinów, wiernych Prawosławnego Autokefalicznego Apostolskiego Kościoła Gruzińskiego. W przyszłości może to doprowadzić do jeszcze większych podziałów i antagonizmów w społeczeństwie gruzińskim.

Kościół Gruziński nie kryje negatywnego stosunku do innych wyznań w Gruzji; postrzega je jako zagrażające religijnej tożsamości narodu. Wyższe duchowieństwo Kościoła Gruzińskiego podejmowało różne inicjatywy mające na celu ograniczenie wpływu innych Kościołów. Według opinii niektórych Gruzinów, „Cerkiew wobec tych ruchów prowadziła politykę sowiecką, stała się instytutem narodowościowym. Chodzenie do cerkwi stało się aktem politycznym na pokaz. Ten boom religijności wiązał się z nacjonalizmem" 57 .

Ekstremiści religijni nie wahali się nawet potępić katolikosa za zaproszenie do Gruzji w 1999 r. papieża. Katolikos wprawdzie spotkał się z Janem Pawłem II, ale nie pozwolił na poruszenie $\mathrm{w}$ rozmowie tematów religijnych i teologicznych, zaś nazajutrz po tym spotkaniu zabronił swym wiernym udziału w katolickiej Mszy świętej odprawionej w hali sportowej w Tbilisi przez Ojca Świętego. Decyzję swoją umotywował pochodzącymi z pierwszych wieków chrześcijaństwa kanonami, zakazującymi wiernym udziału w nabożeństwach sprawowanych przez heretyków, do których Kościół Gruziński zalicza również katolików ${ }^{58}$. Kościół Gruziński wraz z częścią społeczeństwa (masowe protesty studentów, którzy wykrzykiwali hasła: „Jesteśmy przeciwni zawieraniu poddańczego porozumienia z Watykanem”, „Gruzja jest prawosławna”) opowiedział się w 2003 r. przeciwko zawarciu umowy międzynarodowej pomiędzy Gruzją a Watykanem. Według katolikosa umowa

${ }^{54}$ Georgia 2013 International Religious Freedom Report, Department of State USA, www.state.gov/ documents/organization/222429.pdf (dostęp: 15.07.2015).

${ }^{55}$ Dyskryminacja ateistów w Gruzji. Wpływy Cerkwi w interesie Rosji, 21.07.2015, http://onet.tv/i/ dowiedzsie/dyskryminacja-ateistow-w-gruzji-wplywy-cerkwi-w-interesie-rosji/3zdzlh (dostęp: 22.07.2015).

${ }^{56} \mathrm{Na}$ ten aspekt w generowaniu konfliktów zwraca uwagę M.B. McGuire w swojej pracy Religia w kontekście społecznym, tłum. S. Burdziej, Kraków 2012, s. 259.

57 D. Zadura, Naród w tygrysiej skórze..., s. 286.

58 Szef watykańskiej dyplomacji oburzony postawa Gruzji, Katolicka Agencja Informacyjna (KAI) 21.09.2003, http://ekai.pl/wydarzenia/x5651/szef-watykanskiej-dyplomacji-oburzony-postawagruzji (dostęp: 25.06.2015). 
doprowadziłaby do zaostrzenia stosunków pomiędzy Kościołem Gruzińskim a Watykanem i wywołałaby niezadowolenie przedstawicieli innych wyznań religijnych w Gruzji ${ }^{59}$. Mimo iż umowa miała dotyczyć tylko kwestii międzypaństwowych, a nie kwestii religijnych, Kościół Gruziński rozpoczął gwałtowną kampanię przeciwko niej, a duchowni gruzińscy mieli nawet publicznie głosić, iż umowa ta jest nie do przyjęcia, bowiem przewiduje nawrócenie Gruzji na katolicyzm. Prezydent E. Szewardnadze ugiął się pod presją Kościoła Gruzińskiego i wstrzymał podpisanie umowy ${ }^{60}$.

Uprzywilejowanie w prawie oraz wsparcie ze strony władz pozwoliło Kościołowi Gruzińskiemu na odbudowanie swoich struktur organizacyjnych ${ }^{61}$. Przy odtwarzaniu swoich dawnych jurysdykcji Kościół Gruziński wszedł w zatarg z innymi Kościołami i wyznaniami. Katolikom zabrano pięć świątyń, z czego trzy w dużych miastach (Kutaisi, Gori, Batumi), usunięto znajdujące się w nich nagrobki oraz zniszczono katolickie napisy ${ }^{62}$. Z Azerbejdżanem Gruzja miała spór o zespół klasztorny Dawid Garedża, który w 2009 r. rozwiązano w ten sposób, że kontrolę nad obiektem oddano Gruzji, zaś teren, na którym stoi klasztor, przyznano Azerbejdżanowi ${ }^{63}$. Było to tylko pozorne uregulowanie sprawy. Wobec rozpowszechnianych w Gruzji pogłosek, jakoby azerscy pogranicznicy nie chcieli przepuszczać gruzińskich pielgrzymów i turystów na teren klasztoru Udabno w kompleksie Dawid Garedżi (od czasów radzieckich klasztor Udabno znajduje się w granicach Azerbejdżanu), strona gruzińska rozpoczęła w maju 2012 roku rozmowy na temat jego przekazania ${ }^{64}$. Jednak konsensus wymaga ustępstwa $\mathrm{z}$ obydwu stron, co nie jest łatwe.

Najwięcej konfliktów pojawia się między Kościołem Gruzińskim a Ormiańskim Kościołem Apostolskim. Żądania dotyczą przekazania Ormianom kilku kościołów w Samcche-Dżawachetii oraz kontroli nad średniowiecznymi ormiańskimi klasztorami w Hokaret i Hustap, w Kwemo Kartli (Gruzja).W sporze sięgnięto po różnorakie argumenty, angażując do tego historyków, historyków sztuki, etnografów, pracowników Gruzińskiej Akademii Nauk i przedstawicieli obydwu Kościołów ${ }^{65}$.

Wzajemne relacje między Ormianami i Gruzinami komplikuje ponadto polityka Kościoła Gruzińskiego, który w Samcche-Dżawachetii, gdzie dominują

\footnotetext{
59 T.J. Szyszlak, Stosunki państwa z Apostolskim..., s. 84.

60 Szef watykańskiej dyplomacji oburzony postawa Gruzji,...

${ }^{61}$ Szerzej na ten temat zob: P. Nieczuja-Ostrowski, op. cit., s. 297.

62 Gruzin nie może być katolikiem...

63 A. Curanović, Religie, Kościoły i konflikty..., s. 212.

${ }^{64}$ Грузия ведет переговоры с Азербайджаном о передаче монастыря Удабно входяего в комплекс Давид Гареджи, Православие.Ru. 15.12.2012, http://www.pravoslavie.ru/news/53516.htm; Комплекс Давид Гареджи является культурным памятником Грузии-Грузинский МИД, Православие.Ru, 16.12.2012, http://www.pravoslavie.ru/news/53559.htm (dostęp: 15.06.2015).

65 A. Curanović, Religie, Kościoly i konflikty..., s. 212-213; L. Kończak, op. cit., s. 169.
} 
Ormianie ${ }^{66}$, monastyry i kościoły obsadza gruzińskimi zakonnikami i zakonnicami. Jest to bardzo niebezpieczna polityka, biorąc pod uwagę silne separatystyczne dążenia tamtejszych Ormian ${ }^{67}$. Pierwsze poważne ostrzeżenie Gruzini otrzymali w czasie wojny pięciodniowej. Dziewiętnastego sierpnia 2008 r. Ormianie z terenów Samcche-Dżawachetii i Dolnej Kartli złożyli oświadczenie, w którym opowiedzieli się za utworzeniem w Gruzji państwa federalnego, gdzie terytoria zamieszkałe przez Ormian miałyby uzyskać status suwerennych podmiotów. Domagano się również przypisania na tych terenach językowi ormiańskiemu statusu języka państwowego ${ }^{68}$. W lutym 2011 r. pod ambasadą Szwajcarii w Moskwie (reprezentującą interesy Gruzji w Rosji) miał miejsce mityng Ormian z Dżawachetii, którzy domagali się rozwiązania problemu statusu gruzińskiej diecezji Apostolskiego Kościoła Ormiańskiego, zwrotu zabranych ormiańskich świątyń, klasztorów oraz pamiątek historycznych, zabezpieczenia równych praw i swobód wszystkim zarejestrowanym związkom wyznaniowym w Gruzji oraz przestrzegania rozdziału 19 Konstytucji Gruzji ${ }^{9}$. Bardzo nieprzychylnie odebrano fundację monumentalnej świątyni Sameba - „chwały gruzińskiej cerkwi”, którą wzniesiono w tradycyjnej dzielnicy ormiańskiej w Tbilisi, na miejscu dawnego cmentarza ormiańskiego ${ }^{70}$. Kościoły, które należały do Ormian, były im zabierane i przerabiane na gruzińskie cerkwie. W samym Tbilisi Ormianie żądają zwrotu pięciu swoich dawnych świątyń. Przy tej okazji piętnowane jest niszczenie ormiańskich cmentarzy znajdujących się przy świątyniach. Kwestia własności świątyń stanowi obecnie najpoważniejszy zarzut strony ormiańskiej wobec Gruzinów ${ }^{71}$. Sytuację jeszcze bardziej skomplikowała decyzja Gruzińskiego Kościoła z 6 lutego 2006 r. o utworzeniu pod zwierzchnictwem bp. Dmanisi nowej diecezji Tasziro-Agarackiej, co ma służyć odnowieniu historycznej diecezji Kwemo Kartli. Problem w tym, że powołana do życia diecezja obejmuje południową część Armenii. Apostolski Kościół Ormiański podkreśla, że decyzja ta nie ma podstaw prawnych, bowiem regionu nie zamieszkuje wymagana liczba (minimum tysiąc) wiernych Kościoła Gruzińskiego. Kościół ten zażądał

${ }^{66} \mathrm{Na}$ temat historii Ormian w Dżawachetii szerzej zob.: В. Рамишвили, Армяно-Грузинский спор: Джавахети или Джавахк?, http://www.ca-c.org/c-g/2007/journal_rus/c-g-4/02.shtml (dostęp: 1.07.2015); M. Marjanli, Armenians. Russia. The Caucasus, Dubai 2011, s. 46-55.

${ }^{67}$ W marcu 1995 r. w rejonach Achalkalaki i Achalciche Ormianie demontowali słupy przygraniczne i opowiadali się za przynależnością do Armenii, К.С. Гаджиев, Кавказский узел в геополитических приоритетах России, Москва-Логос 2010, s. 267.

68 В населенном армянами Самихе - Джавахети поднят вопрос об автономии в составе Грузии, REGNUM -Информационное агентство 22.08.2008, http://www.regnum.ru/ news/1043811.html\#ixzz29rSJzn8C (dostęp: 27.08.2015).

69 А. Токарев, Влияние государственности на эволюиию политических режимов Грузии и Украины в 1991-2014 годах, Москва 2015, s. 215.

${ }^{70}$ L. Kończak, op. cit., s. 170.

${ }^{71}$ I. Komoszyńska, Niektóre aspekty współczesnych antagonizmów gruzińsko-ormiańskich, w: Dylematy kaukaskie. Problemy narodowościowe i migracyjne, red. M. Ząbek, Warszawa 2010, s. 315; D. Zadura, Ormiańskie świątynie w Tbilisi, http://www.kaukaz.net/cgibin/blosxom.cgi/polish/ gruzja/gruzja_ormianskie_koscioly (dostęp: 14.06.2015). 
ponadto od Apostolskiego Kościoła Ormiańskiego zwrotu sześciu klasztorów gruzińskich znajdujących się w historycznej dzielnicy Kwemo Kartli. W odpowiedzi na to jeden z posłów parlamentu Armenii zaproponował 22 sierpnia 2007 r. utworzenie oddzielnej diecezji Apostolskiego Kościoła Ormiańskiego w miejscowości Dżawachetia na południu Gruzji, w której Ormianie stanowią 91-97\% mieszkańców ${ }^{72}$. W 2011 r. Kościół Ormiański uzyskał status prawny w Gruzji, natomiast takiej samej pozycji nie doczekał się do tej pory Kościół Gruziński w Armenii. Kościół Gruziński zgłasza pretensje do znajdujących się w regionie Lori czterech klasztorów Akhtala, Kobayr, Hnevank i Huchap oraz znajdującego się w regionie Tavush klasztoru Kirantsky. Kościół Ormiański nie zgadza się na to, podając jako podstawowy powód dwa argumenty - historyczne klasztory gruzińskie, które działały w XI-XII wieku podlegały Ormiańskiemu Kościołowi Apostolskiemu i tak powinno pozostać, poza tym w Armenii według oficjalnych danych ${ }^{73}$ mieszka tylko 600 etnicznych Gruzinów, co również przemawia za tym, aby pozostać przy stanie obecnym ${ }^{74}$. Na terenie Dżawachetii, w kilku małych miejscowościach i wsiach w okolicach Achalkalaki i Achalcyche występują jeszcze Ormianie katolicy, zwani potocznie „Frankami”75. Stanowią odrębną grupę religijną w Gruzji i podlegają Ordynariatowi Europy Wschodniej dla Ormian katolików, który został utworzony w 1991 r., i na którego czele stoi od 2011 r. abp Rafael Minassian.

W Adżarii po zakończeniu rządów Asłana Abaszydzego Kościół Gruziński rozpoczął politykę akcentowania chrześcijańskiego dziedzictwa tego regionu. $\mathrm{W}$ telewizji Adżaria, podległej władzom autonomii, emituje się często programy religijne przygotowywane wspólnie z patriarchatem. Nie ma zaś audycji skierowanych do adżarskich muzułmanów ${ }^{76}$, którzy stanowią ok. 48\% mieszkańców tego regionu. Coraz częściej wielu młodych Adżarów, aby stać się pełnoprawnymi Gruzinami (m.in. znaleźć pracę), decyduje się na przyjęcie prawosławia. Na pewno duży wpływ na to ma przedstawianie religii muzułmańskiej jako wroga, który przez tysiąclecia próbował zniszczyć naród gruziński. Walka z islamem ukazywana jest, jako „wojna cywilizacji” "77. Kościół Gruziński wydaje miliony publicznych pieniędzy na budowę kościołów i seminariów w adżarskich miejscowościach, a lokalne duchowieństwo

72 A. Curanović, Rosyjsko-kaukaskie sasiedztwo..., s. 385.

${ }^{73}$ Dane na rok 2011.

${ }^{74}$ G. Abramian, Армения: Имущественные споры способствуют эскалации напряженности между церквями Армении и Грузии 11VIII 2011, Eurasianet.org, http://russian.eurasianet.org/ node/58814 (dostęp: 20.06.2015).

75 Prowadzone są osobne badania poświęcone tej grupie - np. w 2012 r. projekt Fundacji Wyszehradzkiej Franks - Armenian Catholics in Georgia.

${ }^{76} \mathrm{Na}$ temat muzułmanów w Adżarii szczegółowo w pracy Ruslana Baramidze, Islam in Adjara Comparative Analysis of Two Communities in Adjara, w: Changing Identities: Armenia, Azerbaijan, Georgia. Collection of Selected Works, ed. V. Voronkov, Tbilisi 2011, s. 96-125.

77 Р. Силантьев, Религиозньй фактор во внешнеполитических конфликтах на Кавказе, w: Религия и конфликт, ред. А. Малашенко, С. Филатов, Москва 2007, s. 131-132; L. Kończak, op. cit., s. 170-171; A. Curanović, Rosyjsko-kaukaskie sasiedztwo..., s. 384. 
prawosławne zachęca swoich wiernych do namawiania ich muzułmańskich sąsiadów na zmianę religii ${ }^{78}$.

Wzmacnianiu pozycji muzułmanów w Gruzji Kościół Gruziński jest nieustannie przeciwny. W czasie rozmów prowadzonych 27 marca 2013 r. między szefem tureckiej dyplomacji Ahmetem Davutoğlu i premierem Bidziną Iwaniszwilim, przewodniczącym parlamentu Dawitem Usupaszwilim, minister spraw zagranicznych Mają Pandżykidze, ministrem do spraw reintegracji Paatą Zakareiszwilim oraz katolikosem Ilią II poruszono kwestię repatriacji Meschetyńców oraz budowy nowego meczetu w Batumi. Ta ostatnia sprawa spotkała się z licznymi zastrzeżeniami władz kościelnych, mimo to premier zapowiedział swoje poparcie ${ }^{79}$.

Katolikos nie wyraził zgody na przekazanie zabranych budynków sakralnych Ormiańskiemu Kościołowi Apostolskiemu w zamieszkałej w większości przez Ormian Samcche-Dżawachetii, ani na budowę meczetów dla mieszkających w Adżarii muzułmanów, co spowodowało przeniesienie sporów religijnych na grunt międzypaństwowy. Utrudniało to władzom państwowym prowadzenie polityki zagranicznej, tym bardziej że Kościół Gruziński występował z krytyką ich posunięć. Pod koniec 2011 r. Ilia II wysłał do tureckiego premiera list z prośbą o zwrot kilku cerkwi znajdujących się w północno-wschodniej Turcji ${ }^{80}$, uznając za niesprawiedliwe to, że podczas gdy odbudowuje się meczety w Gruzji, w państwie tureckim niszczeją gruzińskie cerkwie. Tymczasem władze gruzińskie, nie czekając na nadesłanie odpowiedzi katolikosowi, pod jego nieobecność w kraju, wyraziły gotowość do odbudowy meczetów w Gruzji w zamian za restaurację cerkwi na terenie Turcji. W odpowiedzi na wstępną umowę, w której rządy Gruzji i Turcji omówiły kwestie wzajemnej ochrony obiektów religijnych ${ }^{81}$, patriarchat Gruzji opublikował 9 lutego 2012 r. swoje stanowisko, w którym oskarżył władze w Turcji o prowadzenie odrębnych negocjacji oraz podkreślił, że właśnie

78 М. Корсо, Грузия: Растёт дискриминация в отночении мусульман? 7.09.2013, Eurasianet. org, http://russian.eurasianet.org/node/60279 (dostęp: 20.06.2015).

79 W. Wojtasiewicz, Wybory za pasem, Nowa Europa Wschodnia (NEW) 4.04.2013, www.new.org. pl/2013-04-04,wybory_za_pasem.html (dostęp: 5.06.2015).

${ }^{80}$ Jedną z cech gruzińskiego monastycyzmu jest wielowiekowa tradycja udawania się mnichów poza granicę i zakładania klasztorów w różnych miejscach, przy jednoczesnej dbałości o zachowanie ich narodowego charakteru, J.M. Laboa, Monastycyzm gruziński, w: Mnisi Wschodu i Zachodu. Historia monastycyzmu chrześcijańskiego, red. J.M. Laboa, Warszawa 2009, s. 166.

${ }^{81}$ Kwestie te również reguluje umowa konstytucyjna - w art. 10 jest zapis: „Państwo bierze na siebie obowiązek przeprowadzenia rozmów z odpowiednimi państwami o ochronie wszystkich znajdujących się na ich terytorium gruzińskich, prawosławnych cerkwi, klasztorów, ich ruin, innych budowli kościelnych, przedmiotów kościelnych, a także o ich konserwacji i zarządzaniu nimi”, Porozumienie Konstytucyjne między Państwem Gruzińskim..., s. 363.17 lipca 2014 r. została podpisana umowa między państwem a Kościołem Gruzińskim o wspólnej ochronie dziedzictwa kulturowego Gruzji, Государство и Церковь в Грузии будут вместе сохранять культурное наследие, Образованне и Православие 20.07.2014, http://www.orthedu.ru/hppc/ news-hppc/10797-gosudarstvo-i-cerkov-v-gruzii-budut-vmeste-sohranyat.html (dostęp: 20.12.2015). 
w taki sposób prowokuje się konflikty między muzułmanami i chrześcijanami. Politycznym ostrzeżeniem władz była zorganizowana w Batumi tzw. msza ostrzegawcza - protest wyznawców prawosławia przeciwko porozumieniu gruzińsko-tureckiemu ${ }^{82}$. Nowy rząd Bidziny Iwaniszwilego zdecydował się jednak na prowadzenie dalszych rozmów z Turcją w sprawie ochrony praw muzułmanów na terenie Gruzji. Pierwsze rozmowy na temat budowy nowego meczetu w Batumi zostały podjęte przez B. Iwaniszwilego podczas jego podróży do Turcji w lutym 2013 r., a następnie kontynuowane przez ministra spraw zagranicznych Turcji Ahmeta Davutoğlu, który miesiąc później przybył do Gruzji. Podjęto wtedy również temat odrestaurowania gruzińskiego budownictwa sakralnego w północno-wschodniej Turcji oraz skomplikowany problem repatriacji Meschetyńczyków ${ }^{83}$. Również katolikos rozpoczął w sierpniu 2014 r. rozmowy z władzami tureckimi na temat uzyskania statusu prawnego przez Kościół Gruziński w Turcji i możliwości wznowienia działalności w historycznych świątyniach znajdujących się na terenie Turcji ${ }^{84}$.

Po wyborach parlamentarnych w 2012 r., kiedy głos środowisk konserwatywno-narodowych uległ wzmocnieniu, wzrosła też temperatura nastrojów konserwatywno-nacjonalistycznych. Ich przejawem były zamieszki, jakie wybuchły 26 sierpnia 2013 r. na południu kraju we wsi Chela, zamieszkanej przez Gruzinów prawosławnych i wyznania muzułmańskiego, po dokonanym przez miejscowe władze demontażu minaretu miejscowego meczetu. Powodem tego miała być samowola budowlana i nieprawidłowości przy wwozie minaretu z Turcji. Rząd nie zareagował (mimo że Gruziński Związek Muzułmanów zaapelował do premiera Iwaniszwilego o interwencję), a napięcie zostało rozładowane w wyniku mediacji między środowiskami muzułmańskimi a Ilią II ${ }^{85}$. Katolikos stwierdził, że siły, które spowodowały konfrontację między chrześcijanami a muzułmanami, miały na celu zdyskredytowanie Kościoła i państwa ${ }^{86}$. Wystąpienia przeciw muzułmanom trwają jednak nadal. W Kobuleti w Adżarii Gruzini zaprotestowali przeciwko budowie muzułmańskiej szkoły, zawieszając na jej drzwiach głowę świni ${ }^{87}$.

82 R. Król-Mazur, op. cit., s. 290.

${ }^{83}$ W. Wojtasiewicz, Polityka zagraniczna Republiki Gruzji pod rzadami premiera Bidziny Iwaniszwilego - kontynuacja czy zmiana?, w: Prawo i polityka na wschód od Europy, red. J. Marszałek-Kawa, P. Wawrzyński, Toruń 2014, s. 142-143.

${ }^{84}$ Patriarch Ilia II asking Turkish authorities to resume services at Georgian churches, Tbilisi 13.09.2014, http://www.pravoslavie.ru/english/73691.htm (dostęp: 20.06.2015).

${ }^{85}$ M. Matusiak, Wzrost nastrojów konserwatywno-nacjonalistycznych?, Ośrodek Studiów Wschodnich, 4.09.2013, http://www.osw.waw.pl/publikacje/analizy/2013_09_04/gruzja-wzrost-nastrojowkonserwatywno-nacjonalistycznych (dostęp: 4.06.2015).

${ }^{86}$ K. Kakachia, Is Georgia's Orthodox Church an Obstacle to European Values? PONARS Eurasia Policy Memo No. 322 June 2014, s. 3 http://www.ponarseurasia.com/sites/default/files/policy-memos-pdf/Pepm_332_Kakachia\%20_June\%202014.pdf (dostęp: 20.12.2015).

87 Patriarch Ilia II asking Turkish authorities to resume services at Georgian churches, Tbilisi 13.09.2014, http://www.pravoslavie.ru/english/73691.htm (dostęp: 20.06.2015). 
Gruziński premier B. Iwaniszwili, starając się rozwiać obawy dotyczące dyskryminacji mniejszości etnicznych i religijnych w Gruzji, wielokrotnie podkreślał, iż Gruzja jest krajem tolerancyjnym, a 2 września 2013 r. przed korpusem dyplomatycznym zapewniał przedstawicieli społeczności muzułmańskiej, że „tolerancja religijna, to nie tylko nasza tradycja, ale także jedna z podstawowych zasad konstytucji Gruzji" ${ }^{88}$. Rzeczywistość jest jednak odmienna, a Kościół Gruziński ma duży udział w jej kształtowaniu.

Cała ta sytuacja staje się coraz bardziej niebezpieczna, bowiem według George Sanikidze, dyrektora Instytutu Orientalistyki na Państwowym Uniwersytecie Ilia w Tbilisi, muzułmanie w Gruzji również przeżywają swoje odrodzenie religijne ${ }^{89}$.

Według raportu sporządzonego w 2014 r. przez organizację Human Right Watch, muzułmanie w Gruzji są nadal przedmiotem ataków ze strony ludności prawosławnej. W regionach, gdzie ludność ta stanowi znaczny odsetek, nie pozwala im się na modlitwy w domach zamienionych na meczety. Dochodzi do różnych incydentów, jak chociażby ten z kwietnia 2014 r., gdy w jednej ze wsi w regionie Adżarii trzech pijanych policjantów zatrzymywało samochody, dokonując rewizji podróżujących, nazywając ich Tatarami i żądając pokazania krzyża na szyi ${ }^{90}$. Wobec coraz częstszych przejawów konfliktów społecznych w Gruzji, dochodzi również do większych tarć między ludnością chrześcijańską a muzułmańską w tym kraju ${ }^{91}$. Podobnie jak rząd, również Kościół Gruziński nie chce repatriacji Turków meschetyńskich na terenach Samcche-Dżawachetii (ten pierwszy nie chce konfliktów z mieszkającymi tam Ormianami, których Rosjanie osiedlali w miejsce Turków meschetyńskich od połowy XIX w., a ten drugi nie życzy sobie więcej muzułmanów w kraju). Gruzini są negatywnie nastawieni do Turków meschetyńskich, rząd zaś to wykorzystuje, piętrząc trudności związane z uzyskaniem statusu repatrianta ${ }^{92}$. Choć w 2012 r. Gruzja przyjęła na siebie obowiązek repatriacji do Gruzji tysięcy Meschetyńców ${ }^{93}$, to w ich kwestii sytuacja niewiele się zmieniła. Dla Gruzji priorytetem jest zapewnienie stabilności w rejonie

${ }^{88}$ М. Корсо, Грузия: Растёт дискриминация в отномении мусульман? 7.09.2013, Eurasianet. org, http://russian.eurasianet.org/node/60279 (dostęp: 20.06.2015).

${ }^{89}$ Ibidem.

90 Human Rights World Report 2014: Georgia, http://www.hrw.org/world-report/2014/country-chapters/georgia (dostęp: 10.12.2015).

91 M. Falkowski, Gruzja: kryzys polityczny i rosyjskie zagrożenie, Analizy Ośrodka Studiów Wschodnich, http://www.osw.waw.pl/pl/publikacje/analizy/2014-11-19/gruzja-kryzys-polityczny-i-rosyjskie-zagrozenie (dostęp: 10.12.2015).

92 T. Trier, G. Tarkhan-Mouravi, F. Kilimnik, Meskhetian: Homeward Bound..., Tbilisi 2011, s. 42-47; 101; V. Modebadze, Historical Background of Meskhetian Turks' Problem and Major Obstacles to the Repatriation Process, „IBSU Scientific Journal” 3 (2009), 1, s. 124-126.

93 W 1999 r. rząd gruziński zobowiązał się do repatriacji i reintegracji Meschetyńców w ciągu dwunastu lat (był to warunek członkostwa Gruzji w Radzie Europy); zob. T. Pataraia, Rozwój polityki migracyjnej w Gruzji, w: Polityka migracyjna Gruzji: wnioski z polskich doświadczeń, red. P. Kaźmierkiewicz, T. Pataraia, Warszawa 2011, s. 117. 
Samcche-Dżawachetii, bowiem przebiega tamtędy rurociąg Baku-Tbilisi-Ceyhan oraz gazociąg Baku-Tbilisi-Eszurum.

Informacje o dyskryminacji muzułmanów w Gruzji budzą zaniepokojenie w sąsiednich krajach muzułmańskich. W sierpniu 2013 r. katolikos przyjął delegacje irańskiego duchowieństwa na czele $\mathrm{z}$ ajatollahem Shahritsanem. Celem wizyty było zbadanie sytuacji muzułmanów na Kaukazie i stosunków między nimi a chrześcijanami. Ilia II, korzystając $\mathrm{z}$ okazji, zaapelował do Shahritsana o niekaranie Gruzinów od kilku wieków zamieszkujących w Iranie za przechodzenie na prawosławie i powrót do wiary przodków ${ }^{94}$.

Problem jest również z powołaniem komisji mieszanej, która ma zająć się rozwiązaniem najbardziej drażliwych problemów między katolikami a prawosławnymi (m.in. kwestią odebranych kościołów, uznaniem chrztów katolickich). Zwalczane są znaki i symbole katolickie - zdarzało się, że dzieci, które w szkole przeżegnały się po katolicku, były bite po rękach. Kościół Gruziński z ogromną niechęcią odnosi się do działalności Caritas prowadzonej w Gruzji przez Kościół katolicki, bo jak miał powiedzieć Ilia II: „My się was boimy, jesteście Kościołem wielkim, bogatym i dobrze zorganizowanym, a my malutkim, odradzającym się dopiero po zniszczeniach komunizmu. Jesteście dla nas zagrożeniem" ${ }^{15}$. Caritas jest jedyną instytucją, która pomaga kilkuset tysiącom uchodźców, m.in. z Osetii Południowej, zapewniając im codzienny skromny posiłek. Działa w utrudnionych warunkach, bez funduszy, bowiem w mediach temat uchodźców jest niepożądany, bo tworzy rządowi zły image ${ }^{96}$.

Oskarżany o szowinizm religijny Kościół Gruziński, mimo interwencji organizacji międzynarodowych i napomnień ze strony Rady Europy, twardo stał na stanowisku utrzymania uprzywilejowanej pozycji ${ }^{97}$. Sterowany przez niego ekstremizm religijny był początkowo tolerowany przez rządzących. Sytuacja częściowo uległa zmianie po dojściu do władzy Michaela Saakaszwilego. Już w dobie „rewolucji róż”, chcąc pozyskać gruzińską inteligencję, rozpoczęto walkę z religijnym ekstremizmem. Władze zorganizowały kampanię propagandowo-informacyjną pod hasłem „Celebrujemy gruzińską różnorodność" ${ }^{98}$, która miała przypominać

94 Илия II попросил Иран не наказывать грузин, возвращающихся в Христианство 21.08.2013, Образование и Православие http://www.orthedu.ru/news/7731-iliya-ii-poprosil-iran-nenakazyvat-gruzin-vozvrashhayushhixsya-v-xristianstvo.html (dostęp: 25.06.2015).

95 Gruzin nie może być katolikiem...

96 A. Dzieduszycka-Manikowska, Dramat kościoła na Kaukazie, PCh24.pl 4.08.2013, http://www. pch24.pl/Mobile/Informacje/informacja/id/16759 (dostęp: 12.08.2015).

97 W kwietniu 2011 r. Zgromadzenie Parlamentarne Rady Europy wyraziło w rezolucji zaniepokojenie sytuacją prawną mniejszości, podkreślając „brak odpowiedniego statusu prawnego i ochrony prawnej grup i wyznań innych niż GCP [Gruzińska Cerkiew Prawosławna]”. Rada Europy chwali Gruzję. Cerkiew protestuje, http://www.kaukaz.info/rada-europy-chwali-gruzje-cerkiew-protestuje. html (dostęp: 29.06.2014).

98 Tbilisi porównywane jest do Jerozolimy - jest miejscem spotkań różnych kultur, narodów i wyznań. W mieście można spotkać muzułmański meczet, żydowską synagogę, kościół ormiański, 
mieszkańcom Gruzji o tradycyjnej w ich kraju tolerancji etnicznej i religijnej ${ }^{99}$. Kwestie wolności religii, niemożności rejestracji związków wyznaniowych oraz szerzenia mowy nienawiści przez organizacje i ugrupowania chrześcijańskie w Gruzji w stosunku do osób o odmiennej orientacji seksualnej były problemami, które wielokrotnie podnosili kolejni ombudsmani w tym kraju ${ }^{100}$. Ich działania niewiele jednak mogły zmienić, bowiem często parlament przyjmował ich sprawozdania tylko do wiadomości, nie podejmując stosownych uchwał ${ }^{101}$.

Ze względu na aspiracje Gruzji do przystąpienia do Unii Europejskiej władze były zmuszone podejmować kroki i decyzje, które stały w sprzeczności ze stanowiskiem i działalnością Kościoła Gruzińskiego. Rząd M. Saakaszwilego podejmował działania w celu ukrócenia działalności osób jawnie dopuszczających się przemocy wobec mniejszości religijnych - przykładem może być ekskomunikowany już wcześniej przez Patriarchat Gruziński fanatyczny duchowny Bazyli Mkalawiszwili ${ }^{102}$. Co jednak istotne, działalność Mkalawiszwilego została w badaniach przeprowadzonych w 2003 r. oceniona przez 45,2 procent respondentów jako „dodatnia"103.

Pozycja Kościoła Gruzińskiego uległa zachwianiu 6 lipca 2011 r., kiedy weszła w życie ustawa zmieniająca status mniejszości religijnych w Gruzji - do tej pory były one uznawane za niekomercyjne podmioty prawa prywatnego. Pierwsze próby zrównania statusu prawnego Kościoła Gruzińskiego i innych związków wyznaniowych podjęto w grudniu 2005 r., jednak część gruzińskich parlamentarzystów udaremniła je, nie biorąc udziału w głosowaniu ${ }^{104}$. Ustawa z 2011 r. umożliwiła Ormiańskiemu Kościołowi Apostolskiemu, Kościołowi Rzymskokatolickiemu, Ewangelickiemu Kościołowi Baptystycznemu oraz wspólnotom skupiającym muzułmanów i Żydów rejestrację, jako podmioty prawa publicznego. Zmiany te zostały bardzo ostro skrytykowane przez Patriarchat, który zdecydował się nawet na wyprowadzenie wiernych na ulice. Przeciwko nowej regulacji prawnej protestowało przed parlamentem kilka tysięcy osób, na czele z księżmi prawosławnymi. Marsze protestacyjne odbyły się 9, 10 i 11 lipca. Katolikos Ilia II pobłogosławił protestujący tłum, a w pierwszym wydanym oświadczeniu stwierdził,

kościół katolicki zw. też polskim, rosyjską cerkiew prawosławną, zbór luteranów i baptystów. Mieszkają tu przedstawiciele ponad 90 narodów i grup etnicznych, D. Parzymies, Życie codzienne $w$ Tbilisi 1999-2003, Warszawa 2004, s. 37-44; 93-119.

99 L. Kończak, op. cit., s. 169.

100 M. Wróblewski, Partnerstwo na rzecz praw człowieka. Współpraca z Ombudsmanem Gruzji w ramach programu ombudsmanów państw Partnerstwa Wschodniego UE, w: Gruzja między Wschodem a Zachodem, red. K. Masiuk [et al.], Kraków-Warszawa 2012, s. 108.

101 W 2007 r. parlament odmówił oficjalnej możliwości zaprezentowania rocznego sprawozdania przez Sozara Subari, L. Leszczenko, Instytucja ombudsmana w państwach proradzieckich. Geneza - status prawny - rozwój, Warszawa 2011, s. 127.

102 A. Szabaciuk, Między konfliktem a pokojem. Polityka etniczna i wyznaniowa Gruzji w latach 1991-2012, „Wschodnioznawstwo” 2012, s. 68-69.

103 The Political Landscape of Georgia..., s. 72.

104 A. Curanović, Rosyjsko-kaukaskie sąsiedztwo..., s. 383. 
że przyjęta ustawa zagraża specjalnej pozycji Kościoła Gruzińskiego i że nadanie osobowości prawnej innym wyznaniom w Gruzji powinno się odbyć wtedy, gdy Kościół Gruziński otrzyma taką w innych krajach (chodziło zwłaszcza o Armenię). Wystąpił również z gniewnym oświadczeniem pod adresem rządu, który przyjmując takie prawo, poniżył Kościół Gruziński ${ }^{105}$. Zapewnił, że „to prawo jest ważne, ale też bardzo niebezpieczne, więc ustawodawcy powinni przemyśleć, jakie może mieć konsekwencje w przeciągu dziesięciu czy stu lat..."106. Partia Chrześcijańsko-Demokratyczna rozpoczęła zbieranie podpisów w celu oficjalnego uznania prawosławia jako religii państwowej ${ }^{107}$.

Z perspektywy obozu rządzącego nowa regulacja miała najprawdopodobniej na celu poprawę stosunków z mniejszościami narodowymi, w szczególności z ormiańską - zamieszkującą w zwartych skupiskach południe kraju, słabo zintegrowaną z resztą kraju i ciągle oskarżaną o separatyzm. Kościół Gruziński „kierował” masowymi protestami przeciwko ustawie, bowiem obawiał się roszczeń majątkowych Kościoła ormiańskiego (przed 1917 r. na terytorium Gruzji znajdowało się według różnych źródeł od 457 do 600 świątyń i klasztorów ormiańskich). Potwierdza to również zachowanie rozwścieczonych gruzińskich wiernych, którzy 10 lipca 2011 r. na Placu Tsamebuli Ketevan w Tbilisi zaatakowali kilku Ormian i dotkliwie ich pobili. Arnold Stepanian, szef Organizacji Ormian w Tbilisi oświadczył, że szum związany z ustawą z 6 lipca przyczynił się do wzrostu nastrojów wrogości do Ormian, i że w Gruzji budzi się armenofobia. Autorytatywny biskup Zenon z Dmanisi w swoim przemówieniu z 7 lipca w radio „Maestro” wskazał na Apostolski Kościół Ormiański i władze Armenii jako głównych odpowiedzialnych za uchwalenie przez parlament gruziński wyżej wymienionej ustawy ${ }^{108}$.

Dwunastego lipca 2011 r. parlament Gruzji wniósł poprawki do przyjętego już prawa. Politycy partii rządzącej uspokajali Patriarchat, zapewniając ustami Nugzara Ciklauriego, że Kościół Gruziński zachowa specjalny status gwarantujący mu pewne przywileje fiskalne ${ }^{109}$. I tak w budżecie na 2014 r. przeznaczono 25 milionów lari (około 14,4 mln dolarów) na dofinansowanie Kościoła Gruzińskiego ${ }^{110}$.

105 W. Wojtasiewicz, „Wojna religijna” i afera szpiegowska w Gruzji, „NEW” 2011, 18 VII, www. new.org.pl/2011-07-18,wojna_religijna_i_afera_szpiegowska_w_gruzji.html (dostęp: 20.07.2014); В. Мальцев, Илия II: „Не унижайте Церковь!” Маситабные протесты православных верующих заставили власти Грузии свернуть с европейского пути http://www.religare. ru/2_87652.html (dostęp: 26.06.2015).

106 Cerkiew protestuje przeciwko nowemu prawu, http://www.kaukaz.info/cerkiew-protestuje-przeciwko-nowemu-prawu.html (dostęp: 29.06.2014).

107 В. Мальцев, op. cit.

108 Ibidem.

109 Ibidem; Г. Двали, Грузия отделилась от иеркви, „Коммерсанть” 7.07.2011; Ormianie w Gru$z j i$, http://www.fundacjaormiańska.pl/ormianie-w-gruzji/ (dostęp: 20.07.2015); Gruzińska Cerkiew krytykuje nowe przepisy, http://wiadomosci.wp.pl/kat,1356,title,Gruzinska-Cerkiew-krytykujenowe-przepisy,wid,13573623, wiadomosc.html?ticaid=112548 (dostęp: 20.07.2015).

110 Грузия профинансирует Грузинскую Православную Церковь в размере 25 миллионов лари, Православие.Ru. 8.10.2013, http://www.pravoslavie.ru/news/64750.htm (dostęp: 16.12.2015). 
Katolikos ostro wystąpił przeciwko ratyfikacji przez parlament gruziński Europejskiej Karty Języków Regionalnych lub Mniejszościowych, która gwarantuje mniejszościom narodowym prawo posługiwania się własnym językiem. Dokument ten Gruzja zobowiązała się ratyfikować już w 1999 r. Patriarchat w opublikowanym oświadczeniu stwierdził, że dokument ten przyczyni się do rozwoju tendencji separatystycznych w Gruzji i zmniejszy szanse na przywrócenie integralności terytorialnej Gruzji ${ }^{111}$.

Kościół Gruziński reprezentuje również radykalne stanowisko w sprawie przyznania równych praw mniejszościom seksualnym, czego przykładem były krwawe wydarzenia z 17 maja 2013 r. W zorganizowanych wtedy w Tbilisi masowych i brutalnych protestach przeciwko pikiecie obrońców praw osób homoseksualnych duchowieństwo prawosławne wzięło czynny udział ${ }^{112}$. Wydarzenia te rozgrywały się przy zupełnej bierności policji ${ }^{113}$. Patriarchat Gruzji odgrywa dużą rolę w umacnianiu się homofonicznej postawy ogromnej części społeczeństwa gruzińskiego ${ }^{114}$. Według przeprowadzonych w 2013 r. badań przez Caucasus Resource Research Center znaczna liczba Gruzinów jest skłonna do poszanowania mniejszości religijnych, ale nigdy nie zaakceptuje mniejszości seksualnych, ponieważ godzą one w ich godność narodową i obrażają wartości chrześcijańskie ${ }^{115}$. Radykalizując nastroje społeczeństwa gruzińskiego, Kościół Gruziński przyczynił się do powstanie radykalnych grup wiernych - takich jak np. Unia Prawosławnych czy Chrześcijańscy Rodzice - które odegrały decydującą rolę w starciach z 2012 r. ${ }^{116}$ W kwietniu 2014 r. Kościół Gruziński wyraził ostro swój sprzeciw wobec rządowego projektu ustawy eliminującej wszelkie formy dyskryminacji, sprzeciwiając się zapisowi przewidującemu ochronę prawną przed dyskryminacją ze względu na orientację seksualną i tożsamość płciową ${ }^{117}$. Szczególnie w ostatnich latach rządów M. Saakaszwilego i jego Zjednoczonego Ruchu Narodowego Kościół Gruziński bardzo wyraźnie okazywał krytyczny stosunek wobec uprawianej przez nich prozachodniej polityki

111 M. Tauber, Geopolityka, sytuacja wewnętrzna w Gruzji, a stanowisko Gruzińskiej Cerkwi Prawosławnej, 22.04 2013, www.forum-ekonomiczne.pl/article/geopolityka-sytuacja-wewnętrznaw-gruzji-a-stanowisko-gruzinskiej-cerkwi-prawoslawnej/\# (dostęp: 12.01. 2015).

112 R. Król-Mazur, op. cit., s. 293.

${ }^{113}$ W Gruzji ochroną praw człowieka zajmuje się m.in. jedno ze strukturalnych ogniw MSW Policja Patrolowa, zob. M. Marsagiszwili, Działalność Departamentu Policji Patrolowej Gruzji. Prawa Człowieka, w: Polsko-gruzińska wymiana doświadczeń w zakresie podejmowania czynności służbowych przez funkcjonariuszy policji w aspekcie praw i wolności człowieka, red. I. Nowicka, T. Mosio, Szczytno 2008, s. 31-34.

114 Human Rights World Report 2014: Georgia, http://www.hrw.org/world-report/2014/country-chapters/georgia (dostęp: 10.12.2015); The Georgian Authorities should not water down the country's first anti-discrimination bill, Amnesty International Public Statement 24.04.2014 https:// www.amnesty.org/en/documents/eur56/001/2014/en/ (dostęp: 20.12.2015).

115 A. Chanadiri, Gruzini. Zagubieni Europejczycy, 14.12.2013, http://zw.lt/opinie/gruzini-zagubieni-europejczyzy/ (dostęp: 9.07.2015).

116 K. Kakachia, op. cit., s. 3.

117 Ibidem, s. 5. 
(godzenie się na standardy ochrony różnych mniejszości, w tym i seksualnych), upatrując w niej zagrożenie dla tradycji i twierdząc, że większym zagrożeniem dla Gruzji jest Zachód niż Rosja. To przeświadczenie jest obecne wśród sporej części gruzińskiego duchowieństwa do dzisiaj. Ilia II niejednokrotnie (np. w 2014 r. w życzeniach noworocznych) nawoływał Unię Europejską do uwzględniania dążeń Gruzji do zachowania wartości tradycyjnych kraju i nienarzucania „obcych dla gruzińskiego narodu małżeństw tej samej płci czy ideałów rodzinnych osób tej samej płci”118. To antyzachodnie nastawienie Kościoła Gruzińskiego może w przyszłości ulec wzmocnieniu, tym bardziej że Unia Europejska i Stany Zjednoczone Ameryki udzielają różnego wsparcia również mniejszościom religijnym, włącznie z przyznawaniem pieniędzy na ten cel $^{119}$.

Kościół Gruziński krytykuje również emigrację swoich wiernych, którzy coraz liczniej opuszczają ojczysty kraj, a także jest niechętny napływowi obcych do Gruzji. Katolikos występuje przeciw sprzedaży ziemi obcokrajowcom - według niego zagraża to istnieniu państwa gruzińskiego. Ilia II wzywa władze kraju do zawieszenia procesu sprzedaży ziem gruzińskich obywatelom państw obcych, w celu ściągnięcia do Gruzji obcego kapitału. Podkreśla, że ziemie gruzińskie nie powinny być sprzedawane obcym, a Gruzini nie powinni wspierać obcych pracowników ${ }^{120}$. Należy również pamiętać, że Gruzja stanowi schronienie dla uchodźców z Czeczenii (pochodzi stamtąd $0,7 \%$ imigrantów) ${ }^{121}$, którzy jako wyznawcy islamu nie są mile widziani przez Kościół Gruziński. Ich obecność stanowi również powód pretensji ze strony Federacji Rosyjskiej.

Do wzrostu konfliktów społecznych w Gruzji przyczyniło się zaangażowanie się Kościoła Gruzińskiego w tworzenie polityki historycznej - aktywnie uczestniczy on w tworzenie programów nauczania (w szkołach państwowych naucza się historii religii ${ }^{122}$ ), próbując kontrolować pracę ośrodków naukowych ${ }^{123}$, publiczną telewizję i radio. Staje w obronie stacji telewizyjnych przekazujących treści zgodne $\mathrm{z}$ głoszoną przez siebie nauką ${ }^{124}$. Katolikosat ma także własne

118 R. Król-Mazur, op. cit., s. 294.

119 Ambasada USA przyznaje granty lokalnym organizacjom pozarządowym na wsparcie programów religijnych i pomoc prawną dla mniejszości religijnych, Georgia 2013 International Religious Freedom Report, Department of State USA 28.07.2014, s. 11 www.state.gov/documents/organization/222429.pdf (dostęp: 15.07.2015).

120 Патриархи Грузии: Продажа земли иностраииам ставит под удар сущетвование государста, Православие.Ru. 14.07.2014, http://www.pravoslavie.ru/news/71975.htm (dostęp: 16.12.2015).

121 T. Pataraia, op. cit., s. 114.

122 R. Król-Mazur, op. cit., s. 296.

${ }^{123}$ Katolikos nosił się nawet z zamiarem zbudowania przy kościele Świętej Trójcy hotelu, w którym mógłby przyjmować na kilkudniowych spotkaniach gruzińską inteligencję, ibidem.

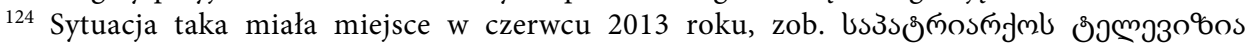

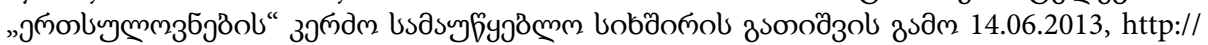
www.patriarchate.ge/?action=news_show\&mode=news\&id=765 (dostęp 4.06.2015). 
media - gazetę „Krzyż z Winorośli” i rozgłośnię „Radio Iweria”125. Ilia II jest zwolennikiem wprowadzenia cenzury, czemu dał wyraz przy okazji prezentacji książki Erekle Deisadze Saidumlo Siroba, która wywołała w Gruzji skandal ze względu na prowokacyjną i obraźliwą treść. Patriarcha uznał tę publikację za przejaw walki w Kościołem i tradycyjnymi gruzińskimi wartościami oraz wyróżnił odznaczeniem kościelnym jednego z duchownych liderów organizacji religijnej, który wziął czynny udział w bójce, jaka rozegrała się w trakcie debaty telewizyjnej na temat tej książki ${ }^{126}$.

Umowa Konstytucyjna jest dowodem na to, że politycy dostrzegli wagę kwestii religijnych. Politycy gruzińscy bardzo często odwołują się do religijnych znaków, łącząc je z symbolami narodowymi. Ze znaczenia Kościoła narodowego jeszcze lepiej zdają sobie sprawę kolejni liderzy polityczni począwszy od Eduarda Szewardnadzego. Premier Gruzji Irakli Garibaszwili publicznie głosi, iż cała historia Gruzji jest oparta na wierze chrześcijańskiej. Podkreśla rolę Kościoła Gruzińskiego i wyraża wdzięczność katolikosowi za jego prace w celu zjednoczenia i wzmocnienia kraju ${ }^{127}$.

Od wielu lat nie ulega zmianie zaufanie, jakim Gruzini obdarzają zwierzchnika swojego Kościoła. Nieustannie znajduje się on na szczycie rankingu popularności - w kwietniu 2014 r. uzyskał $96 \%$ poparcie ${ }^{128}$. Niestety wraz z wiekiem zaczyna mieć coraz mniejszą kontrolę nad tym, co dzieje się w łonie Kościoła - coraz więcej władzy zaczyna zdobywać ultrakonserwatywne duchowieństwo. Jak przyznają niektórzy gruzińscy duchowni, do rozwoju tendencji radykalnych w tamtejszym Kościele prawosławnym przyczynia się w dużym stopniu brak kompetencji duchowieństwa - na przestrzeni ostatnich czterdziestu lat liczba duchownych wzrosła trzydziestoczterokrotnie, ale nie wszyscy otrzymali staranne wykształcenie teologiczne. To właśnie ci duchowni są bardziej skłonni do rozpowszechniania i popierania ultrakonserwatywnych ruchów w łonie Kościoła Gruzińskiego. Biorąc pod uwagę wpływ katolikosa i Patriarchatu gruzińskiego na kształtowanie się opinii publicznej, opisana wyżej sytuacja może mieć daleko idące konsekwencje dla polityki wewnętrznej i zagranicznej Gruzji ${ }^{129}$.

Mimo niechęci do innych wyznań, Kościół gruziński przychylnie odniósł się do wydanego 7 lutego 2014 r. dekretu rządowego w sprawie powołania agencji mającej zająć się wypłacaniem odszkodowań za szkody poniesione w Gruzji przez

125 R. Król-Mazur, op. cit., s. 296.

126 D. Zadura, Liberalna demokracja i prawosławny dżihad w Gruzji, 21.09.2010, www.psz. pltekst-33917/Liberalna-demokracja-i-prawoslawny-dzihad-w-Gruzji (dostęp: 20.06.2015).

127 Премьер-министр Грузии: Вся наша история зиждется на христянской вере, Православие. Ru. 15.12.2014, http://www.pravoslavie.ru/news/70715.htm (dostęp: 16.12.2015).

128 Public Attitudes in Georgia: Results of an apr 2014 Survey, https://www.ndi.org/files/Georgia-April14-Survey-Political-English.pdf (dostęp: 20.06.2015).

129 М. Корсо, Грузия: Православная иерковь может превратиться в очаг нетерпимости? 26.06.2013, Eurasianet.org, https://russian.eurasianet.org/node/60169 (dostęp: 20.06.2015). 
związki wyznaniowe w okresie reżimu radzieckiego ${ }^{130}$. Odszkodowanie i dotacje z budżetu państwa mają otrzymać oprócz Kościoła Gruzińskiego jeszcze cztery inne wspólnoty religijne: muzułmańska, ormiańska, katolicka i judaistyczna. Premier Irakli Garibaszwili, który chce w ten sposób uregulować stosunki między państwem i związkami wyznaniowymi, zapowiedział, że fundusze będą przyznawane proporcjonalnie do liczby wiernych ${ }^{131}$.

Uchwała Świętego Synodu Kościoła Prawosławnego Gruzji z 4 czerwca 2014 r. stanowi swoistą gwarancję jego interesów i jest dopełnieniem umowy konstytucyjnej. Przewiduje ona m.in. powołanie dwustronnej komisji, mającej za zadanie opisanie zabytków kościelnych i religijnych przedmiotów znajdujących się w magazynach gruzińskich muzeów oraz przedstawienie raportu o ich stanie. Kościół Gruziński w ścisłym porozumieniu z Ministerstwem Kultury ma dbać o własność i bezpieczeństwo dziedzictwa kulturowego Kościoła, zarówno na terytorium Gruzji, jak i za granicą. We wszystkich gruzińskich parafiach funkcjonujących poza granicami kraju zostaną powołane centra duchowości gruzińskiej i szkoły niedzielne. Patriarchat wraz z Akademią Duchowną ma być odpowiedzialny za przygotowanie programów nauczania i podręczników dla szkół niedzielnych. W celu odzyskania swoich struktur administracyjnych i obsadzenia parafii w Abchazji i Osetii Południowej postanowiono zwrócić się o pomoc do organizacji międzynarodowych i agencji rządowych, pracujących jako grupy dialogu rosyjsko-gruzińskiego. Święty Synod zgłosił swój sprzeciw wobec ustawy antydyskryminacyjnej, która jest nie do przyjęcia dla Kościoła Gruzińskiego, a także wyraził nadzieję, że w najbliższej przyszłości prawo to zostanie zmienione ${ }^{132}$.

Według danych zawartych w Międzynarodowym Raporcie Wolności Religijnej za 2013 r. w Gruzji jest nadal dużo przypadków łamania tego prawa. Tylko Kościół Gruziński jest finansowany $\mathrm{z}$ budżetu państwa i on też zwolniony jest $\mathrm{z}$ większości podatków. Edukacja religijna w szkole, nad którą pieczę sprawuje Gruziński Kościół, nie może być kontrolowana przez władze szkoły. Preferencje w finansowaniu odbudowy świątyń otrzymuje od rządu Kościół Gruziński. Inne Kościoły - w tym Kościół rzymskokatolicki i Ormiański Kościół Apostolski skarżyły się, że spory o własność kościelną nie były rozwiązywane na podstawie przejrzystego procesu prawnego, tylko na zasadzie indywidualnych przypadków, przy wyraźnemu sprzyjaniu roszczeniom Kościoła Gruzińskiego. Nierozwiązywanie sporów co do przynależności poszczególnych budynków sakralnych do konkretnych Kościołów

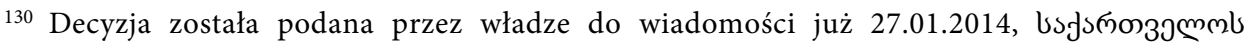

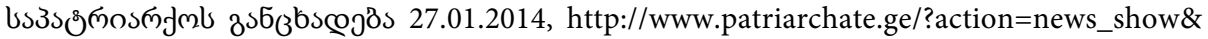
mode $=$ news\&id=789 (dostęp: 22.06.2015).

131 Gruzja: władze zamierzaja finansować Kościół katolicki, „Niedziela” 27.01.2014, http://www. niedziela.pl/artykul/7723/Gruzja-wladze-zamierzaja-finansowac (dostęp: 22.06.2015).

132 Обнародовано постановление Священного Синода Грузинской Православной Церкви 6.06.2014, Образование и Православие http://www.orthedu.ru/hppc/news-hppc/10448-14.html (dostęp: 25.06.2015). 
i przeciąganie tej sytuacji sprzyja narastaniu konfliktów pomiędzy poszczególnymi konfesjami, a także powoduje to, że sporne, zabytkowe budowle popadają w ruinę. Przedstawiciele innych religii skarżyli się na niemożność odzyskania od rządu niektórych swoich budynków, które zostały zarejestrowane jako obiekty dziedzictwa kulturowego - rozmowy takie rząd prowadził przy wsparciu Kościoła Gruzińskiego ze społecznością żydowską w Tbilisi, Gori, Batumi. Do rzecznika praw obywatelskich nadal wpływają liczne skargi od Świadków Jehowy (33 w 2013), a także od muzułmanów, wyznawców Ormiańskiego Kościoła Apostolskiego, zielonoświątkowców, adwentystów i ewangelików. Rzecznik podniósł również problem promowania przez nauczycieli zasad głoszonych przez Kościół Gruziński i posługiwania się na lekcjach emblematami religijnymi. Członkowie mniejszości religijnych obawiają się zgłaszać nadużycia popełniane w szkołach do odpowiedniego departamentu Ministerstwa Edukacji z lęku przed zemstą nauczycieli na dzieciach, a także z przeświadczenia o braku skuteczności podjętych przez nich działań. Innym przykładem nierespektowania w gruzińskich szkołach wolności religijnej jest wyznaczanie egzaminów w soboty, co kłóci się z nakazami religijnymi Żydów i adwentystów. W raporcie wymienione są także konkretne przykłady nadużyć, z jakimi spotkali się przedstawiciele społeczeństwa gruzińskiego ze względu na przynależność do innego związku wyznaniowego. Doniesienia na temat nieposzanowania wolności religijnej w Gruzji Ilia II skomentował szeroko cytowanym w mediach stwierdzeniem, iż obecnie „często jest bardziej uciskana większość” niż mniejszości ${ }^{133}$.

Jak gdyby starając się „zrekompensować” to wszystko innym wyznaniom i Kościołom, rząd bierze udział w różnych organizowanych przez nie uroczystościach. Premier B. Iwaniszwili powitał katolików na Wielkanoc i spożywał razem z przywódcami muzułmańskimi iftar w czasie ramadanu. Biblioteka Narodowa była organizatorem obchodów Międzynarodowego Dnia Pamięci o Holokauście. Ministerstwo Obrony Narodowej zaczęło szkolić w kwestiach wrażliwości religijnej gruzińskie siły zbrojne biorące udział w operacjach międzynarodowych - batalion uczestniczący w misji w Afganistanie uczony był historii, tradycji i zasad islamu. Do końca 2013 r. rząd zarejestrował 22 mniejszościowe grupy religijne jako prawne podmioty prawa publicznego - w tym trzy Kościoła Katolickiego, cztery grupy muzułmańskie, luterańską, jezydzką i dwie żydowskie ${ }^{134}$.

Kościół Gruziński wykazuje także propokojową działalność, starając się łagodzić konflikt między Gruzją i Rosją. Od rozpadu ZSRR Kościół Gruziński i Rosyjska Cerkiew Prawosławna czyniły starania na rzecz dobrej współpracy. Udzielały sobie nawzajem wsparcia w momencie wewnętrznych schizm, jakich obydwa Kościoły doświadczyły w latach 90. Konsekwentnie też bojkotują wspólnoty rozłamowców. Zarówno Kościół Gruziński jak i Rosyjska Cerkiew Prawosławna są nieufne wobec

133 Georgia 2013 International Religious Freedom Report, Department of State USA 28.07.2014 www. state.gov/documents/organization/222429.pdf (dostęp: 15.07.2015).

${ }^{134}$ Ibidem. 
Watykanu i nurtu ekumenicznego. Dwudziestego maja 1997 r. Kościół Gruziński wystąpił ze Światowej Rady Kościołów oraz Europejskiej Rady Kościołów, których członkiem był od 1962 r. ${ }^{135}$ Przedstawiciele Patriarchatu Gruzińskiego aktywnie włączają się w uroczystości organizowane przez Patriarchat Moskiewski. W sierpniu 2013 r. Ilia II wziął udział w 1025 rocznicy chrztu Rusi. W lutym 2014 r. delegacja Patriarchatu Gruzińskiego wzięła udział w uroczystościach mających miejsce w klasztorze Dońskim w Moskwie, gdzie w podziemnych kryptach pochowani są gruzińscy duchowni, przedstawiciele szlachty oraz królewskiej dynastii Imeretii. Głównym celem tej wizyty było odebranie ikony św. Sergiusza, która została wykonana w szkole malarstwa ikon Moskiewskiej Akademii Teologicznej. Ikona ma znaleźć się w gruzińskim klasztorze św. Grzegorza w Alaverdii, w leżącej na północy Armenii prowincji Lori ${ }^{136}$.

Relacje miedzy Kościołem Gruzińskim a Rosyjską Cerkwią Prawosławną komplikuje sprawa Abchazji i Osetii Południowej. W Abchazji równolegle do konfliktu politycznego toczył się konflikt między parafiami abchaskimi, które chciały się uniezależnić od Gruzji i przejść pod jurysdykcję Patriarchatu Moskiewskiego. Kościół Gruziński uważa zaś eparchię (diecezję) abchaską za część swojego obszaru kanonicznego ${ }^{137}$. Cerkiew Rosyjska uznała, że stanowią one część terytorium Kościoła Gruzińskiego. Nie przeszkadza to jej jednak sprawować nieformalną opiekę nad parafiami abchaskimi. Z ramienia Patriarchatu Moskiewskiego prawosławnymi Abchazami opiekuje się biskup Majkowski Pantelejmon. Wzburzenie Kościoła Gruzińskiego wywołało przedstawienie 9 stycznia 2007 r. abchaskiego przekładu Nowego Testamentu w Moskwie i decyzja o przekazaniu egzemplarza tego tłumaczenia parafiom prawosławnym w Suchumi. Kościół Gruziński oskarża Cerkiew Rosyjską o szkolenie w moskiewskim seminarium teologicznym abchaskich duchownych, zaopatrywanie ich w literaturę religijną i przedmioty liturgiczne oraz sprzeczną z prawem kanonicznym działalność duchownych Patriarchatu Moskiewskiego. Oburzenie wywołała również obecność biskupa Stawropola i Władykaukazu, Teofana, na uroczystości zaprzysiężenia nieuznawanego przez władze gruzińskie prezydenta Osetii Południowej, Eduarda Kokoity. Kościół Gruziński nie przyjął także ogłoszonej we wrześniu 2009 r. decyzji Abchaskiego Kościoła Prawosławnego o niezależności od Gruzji ${ }^{138}$. Patriarchat Moskiewski zaś zadeklarował szacunek dla obowiązujących granic jurysdykcji Kościoła Gruzińskiego. Podobne stanowisko zajął również Patriarcha Konstantynopola ${ }^{139}$. W Abchazji

135 R. Król-Mazur, op. cit., s. 299.

136 Московский Патриархат принимает делегацию Грузинской Православной Церкви 13.02.2014, Образование и Православие http://www.orthedu.ru/newОбразование и Православиеs/9388-14.html (dostęp: 25.06.2015).

137 Ilia II przed objęciem urzędu Katolikosa - Patriarchy całej Gruzji był metropolitą suchumsko-abchaskim.

138 A. Curanović, Rosyjsko-kaukaskie sasiedztwo..., s. 389-390; R. Król-Mazur, op. cit., s. 300.

139 G. Hewitt, Discordant Neighbours: A Reassessment of the Georgian-Abkhazian and Georgian-South Ossetian Conflicts, Leiden 2013, s. 284-285; Moscow Patriarchate shall not encourage the 
jednak tamtejszy Kościół podejmuje różne starania w celu usunięcia wszelkiej przeszłości związanej z Kościołem Gruzińskim - np. modyfikowana jest architektura $\mathrm{w}$ celu wyeliminowania wszelkich cech gruzińskich ${ }^{140}$.

Połączenia z Rosyjską Cerkwią Prawosławną domagała się zbuntowana wspólnota w Osetii Południowej, skupiona wokół ojca Aleksandra (Gieorgija Puchajewa). Ponieważ Rosyjska Cerkiew Prawosławna odmówiła, najpierw zdecydowano się na przejście pod jurysdykcję Rosyjskiego Kościoła Prawosławnego Poza Granicami, aby następnie utworzyć diecezję Osetii Południowej - Alanii. Patriarchat Moskiewski również i w tym przypadku nie zaakceptował decyzji o niezależności od Gruzji ${ }^{141}$.

Należy jednak podkreślić, że przyczyną wojny domowej w Gruzji (1992-1994) był nacjonalizm silnie zakorzeniony wśród Gruzinów, Abchazów i Osetyńców, zaś jednym z ważnych komponentów tożsamości zwaśnionych narodów stała się religia.

Sprawdzianem relacji między Kościołem Gruzińskim a Rosyjską Cerkwią Prawosławną stały się wydarzenia z sierpnia 2008 r. Katolikos Ilia II ubolewał, że doszło do konfliktu między dwoma prawosławnymi krajami ${ }^{142}$, ale podkreślał, że nie miał on płaszczyzny religijnej, a jego przyczyny były globalne i polityczne, zaś Gruzja stała się polem walk światowych mocarstw i sił. Nawiązaniem do politycznych wyborów Gruzji (akces do NATO, szkolenie żołnierzy gruzińskich przez wojskowych tureckich) była wypowiedź osetyjskiego bp. Jerzego, który w piśmie skierowanym do katolikosa ubolewał, że w niepamięć poszły doświadczenia wspólnej walki z „muzułmańskim najeźdźcą”, a „teraz Gruzja wzięła sobie za sojusznika islamską Turcję... «ucząc się od tamtejszych instruktorów jak zabijać braci w wierze»" ${ }^{43}$. Ilia II nie tylko wzywał wszystkich do „wstrzymania konfliktu zbrojnego", ale też przypominał, że obydwa narody łączy wielowiekowa przyjaźń, więzy rodzinne i wiara chrześcijańska ${ }^{144}$.

Tradycyjne, bliskie związki z Rosyjską Cerkwią Prawosławną ułatwiły Kościołowi Gruzińskiemu zaangażowanie się w mediacje pomiędzy Gruzją a Rosją, które odegrały szczególnie ważną rolę w czasie wojny pięciodniowej. Katolikos odwiedził rosyjską strefę wojenną i osobiście negocjował z rosyjskim dowództwem wojskowym kwestie zabrania ciał gruzińskich żołnierzy ${ }^{145}$.

separation of the Abkhaz Diocese from Georgian Church 16.09 .2009 http://www.interfax-religion. com/?act=news\&div=6445 (dostęp: 22.06.2015).

140 Georgia 2013 International Religious Freedom Report, Department of State USA, 28.07.2014, s. 8 www.state.gov/documents/organization/222429.pdf (dostęp: 15.07.2015).

141 R. Król-Mazur, op. cit., s. 300.

${ }^{142}$ Co ciekawe, w polskich mediach padały wypowiedzi mówiące o solidarności z Gruzją, bo jest ona „krajem chrześcijańskim”, przy czym pomijano fakt, że wojna ta prowadzona była między dwoma chrześcijańskimi narodami, M. Domagała, Percepcja konfliktu kaukaskiego w polskich mediach $w 2008$ r., Warszawa 2014, s. 371-372.

143 Ibidem, s. 368.

144 Ibidem.

145 Патриарх Илия II: были братьями и останемся братьями 10.08.2013, Образование и Православие http://www.orthedu.ru/news/7667-patriarx-iliya-ii-byli-bratyami-i-ostanemsyabratyami.html (dostęp: 26.06.2015). 
Kościół Gruziński starał się wyciszać narastające uprzedzenia, utrzymując, zwłaszcza po wojnie z 2008 r., oficjalnie nieistniejące stosunki dyplomatyczne. Katolikos interweniował od razu po rozpoczęciu walk, wysyłając list do prezydenta Rosji Dmitrija Miedwiediewa i premiera Władimira Putina. Przeprowadził też rozmowę telefoniczną z metropolitą Kiryłem, kierownikiem Wydziału Zewnętrznych Kontaktów Kościelnych Patriarchatu Moskiewskiego. Ilia II prosił też prezydenta Rosji, by ten nie zatwierdzał postanowienia Dumy o niepodległości Abchazji i Osetii Południowej ${ }^{146}$. Oba patriarchaty (gruziński i rosyjski) zorganizowały pomoc humanitarną dla mieszkańców regionów objętych działaniami wojennymi ${ }^{147}$.

Ilia II zawsze jednak podkreśla, że Abchazja i Osetia Południowa, „to tradycyjne ziemie gruzińskie"148. Dlatego też zareagował błyskawicznie na życzenia złożone przez Patriarchę Moskiewskiego, Cyryla, narodowi Południowej Osetii z okazji 20-tej rocznicy „niezawisłości”. Wystosował do Patriarchy list, w którym napisał, że niezrozumiały jest ten krok, przez który Cyryl „uznaje separatystyczny reżim ustanowiony przemocą, wbrew prawu, na od wieków gruzińskiej ziemi”. Wyraził ubolewanie z powodu wystąpienia Cyryla, zaznaczając, że „Kościół nie powinien ulegać wpływom polityków i politycznych procesów”. Wyraził też wiarę, że tak samo jak w przeszłości, Patriarchat Moskiewski będzie wykazywał troskę o zachowanie kanonicznych granic gruzińskiego prawosławia ${ }^{149}$.

Ilia II cieszy się szacunkiem w Moskwie, czego najlepszym dowodem było wręczenie mu 21 stycznia 2013 r. nagrody Międzynarodowej Społecznej Fundacji Jedności Narodów Prawosławnych „za szczególne zasługi w dziele umacniania braterskich więzi między prawosławnymi narodami i Cerkwiami”"150. Katolikos spotkał się wtedy również z prezydentem Władimirem Putinem, któremu przekazał pozdrowienia od nowego premiera B. Iwaniszwilego ${ }^{151}$. Ilia II jest jednym z nielicznych przedstawicieli Gruzji, którzy mogą bez problemu podróżować z Gruzji na terytorium Federacji Rosyjskiej i jedynym, który oficjalnie spotyka się z najwyższymi przedstawicielami państwa rosyjskiego z Władimirem Putinem na czele, prowadząc negocjacje w najistotniejszych dla interesów Gruzji kwestiach ${ }^{152}$. Ilia II

146 R. Król-Mazur, op. cit., s. 301.

147 J. Ćwiek-Karpowicz, Cerkiew prawosławna w polityce zagranicznej Rosji, Biuletyn PISM, 9.08.2010, nr 110 (718), s. 2281, http://www.pism.pl/zalaczniki/Biuletyn_718_3.pdf. (dostęp: 20.07.2015).

148 Eliasz II Patriarcha Gruzji, http://edu.gazeta.pl/edu/h/Eliasz+II+\%28patriarch+Gruzja\%29\#Dzia. C5.82alno.C5.9B.C4.87_w_Gruzji (dostęp: 22.06.2015).

149 Rosyjsko-gruziński konflikt prawosławny, Radio Watykańskie 27.09.2010, http://www.deon.pl/ religia/kosciol-i-swiat/z-zycia-kosciola/art,3191,rosyjsko-gruzinski-konflikt-prawoslawny.html (dostęp: 16.12.2015).

150 Do Rosji przybywa Katolikos-Patriarcha Gruzji Eliasz II, 20.01.2013, http://polish.ruvr. ru/2013_01_21/Do_Rosji_przybywa_Katolikos_Patriarcha_Gruzji_Eliasz_II (dostęp: 22.07.2015).

151 K. Zasztow, Georgia Dream's Foreign Policie: An Attempt to Change the Paradigm ?, „The Polish Institute of International Affairs Policy Paper" 3(51) (2013), s. 4.

152 Патриарх Илия II... 
w udzielanych wywiadach podkreśla, że kocha Rosję i jej kulturę, a okres studiów spędzonych w seminarium w Rosji pozwolił mu zrozumieć osobowość Rosjan ${ }^{153}$.

Część politologów uważa, że prozachodni kurs władz gruzińskich, który coraz mniej podoba się Kościołowi Gruzińskiemu, jest przyczyną wzmocnienia relacji pomiędzy tamtejszym Kościołem a Patriarchatem Moskiewskim. Kornely Kakachia uważa, że Rosja po wojnie z 2008 roku próbuje łagodniejszych metod przywrócenia swoich wpływów w Gruzji - za pośrednictwem Cerkwi i prawosławnej religii przypomina o wspólnej historii ${ }^{154}$. Dla Patriarchatu Moskiewskiego ważne staje się uregulowanie sytuacji w Abchazji, gdzie dochodzi do kolejnych podziałów (m.in. młodzi księża związani z klasztorem Nowy Athos chcą większego uwzględnienia własnej, chrześcijańskiej tradycji Abchazji i niezależności od Rosyjskiej Cerkwi Prawosławnej) ${ }^{155}$.

Władzom Gruzji problemów przysparzają niektóre publiczne wystąpienia katolikosa, w których wypowiada się na temat sytuacji międzynarodowej, zwłaszcza jeśli dotyczą one najbliższych sąsiadów. Przykładem mogą być słowa wypowiedziane do azerskich duchownych, którzy uczestniczyli w koncercie z okazji 80 . urodzin zwierzchnika Kościoła Gruzińskiego: „Karabach należał i będzie należeć do Azerbejdżanu"156. Oficjalne rząd gruziński zajmuje neutralne stanowisko wobec konfliktu o Górski Karabach, podkreślając konieczność jego pokojowego rozwiązania - takie też było stanowisko premiera B. Iwaniszwilego, kiedy w styczniu 2013 r. złożył wizytę w Armenii ${ }^{157}$.

Analizując relacje między religią a polityką w Gruzji, widzimy, że tożsamość narodowa oparta jest na autoidentyfikacji z religią (widać to dobrze na przykładzie społeczności niegruzińskich, od pokoleń zamieszkujących Gruzję i posługujących się tamtejszym językiem, lecz traktowanych jako „obce” ze względu na "nieprawosławne”, a więc i „niegruzińskie” wyznanie), co rodzi niestety negatywne konsekwencje, bowiem polityka świadomie (bądź mimowolnie) wykorzystuje to do osiągnięcia własnych celów. Religia postrzegana jest jako ważny element narodowej tradycji, zaś zwrot ku tradycji stanowi cechę charakterystyczną większości społeczeństw postradzieckich. Dla elit władzy jest to również korzystne, albowiem mogą one posługiwać się argumentem tradycji przy odpieraniu zarzutów o brak reform systemowych ${ }^{158}$. Religia została poddana instrumentalizacji i wykorzystana

153 Ibidem.

154 Dyskryminacja ateistów w Gruzji. Wpływy Cerkwi w interesie Rosji 21.07.2015 http://onet.tv/i/ dowiedzsie/dyskryminacja-ateistow-w-gruzji-wplywy-cerkwi-w-interesie-rosji/3zdzlh (dostęp 22.07.2015).

155 A. Curanović, Religie, Kościoły i konflikty..., s. 219.

156 Katolikos Eliasz II: Abchazja i Osetia Południowa przynależa do Gruzji...

157 W. Wojtasiewicz, Polityka zagraniczna Republiki Gruzji pod rządami..., s. 142.

158 Problem ten poddała ogólnej analizie A. Curanović, Kontrolowana „zemsta Boga”: znaki szczególne poradzieckiego systemu wyznaniowego, w: Religia i polityka na obszarze Europy Wschodniej, Kaukazu i Azji Centralnej, red. T. Stępniewski, Lublin-Warszawa 2013, s. 35-48. 
do osiągnięcia bieżących celów politycznych. Zarazem Kościół Gruziński „wchodzi w politykę", angażując się w działania, które są ściśle związane z szeroko rozumianą polityką. Władza polityczna przejawia daleko idącą troskę o sprawy religijne, a to zachęca Kościół Gruziński do popierania takiej władzy. Można wręcz zaryzykować stwierdzenie, że przez pewien czas mieliśmy w Gruzji do czynienia z sytuacją, w której polityka pełniła służebną rolę względem religii. Można powiedzieć, że postępowanie Kościoła Gruzińskiego potwierdza tezę postawioną przez Patricka Michela, że „religia, wbrew swej oficjalnej misji, polegającej na głoszeniu tego, co uniwersalne, służy w pierwszym rzędzie do wyrażania - i uzasadniania - tego co partykularne [...] Zamiast stać się miejscem rozwiązania napięć i konfliktów, religia, wspierając i utwierdzając budowanie tożsamości o charakterze nacjonalistycznym, staje się miejscem wykluczenia innego"159. W Gruzji dobrze widoczna jest rywalizacja między państwem a Kościołem Gruzińskim w zakresie wykorzystywania religii w celach polityczno-ideologicznych, dla mobilizacji społeczeństwa ${ }^{160}$. Można powiedzieć, że $\mathrm{w}$ kraju tym mamy do czynienia $\mathrm{z}$ pokusą zamienienia polityki w religię, a z religii uczynienia polityki. Duchowni angażują się (zarówno pośrednio jak i bezpośrednio) w konflikty etnoreligijne oraz społeczne, które mają miejsce w tym kraju. Występuje jednak zróżnicowanie zaangażowania duchowieństwa w zależności od regionu, wielkości ośrodków religijnych. Aspektem pozytywnym tych działań są starania na rzecz zniwelowania konfliktów ${ }^{161}$, natomiast aspektami negatywnymi - wspieranie przez część kleru ugrupowań nacjonalistycznych, udzielanie specjalnego błogosławieństwa osobom biorącym udział w konfliktach, zabieranie świątyń wyznawcom innych religii i budowanie ich na pograniczach etnoreligijnych. Szczególne znaczenie ma tu głos zwierzchnika Kościoła Gruzińskiego - katolikosa, który ciesząc się największym zaufaniem społeczeństwa, ma największe możliwości wpływania na rozwój sytuacji w tym kraju. Słuszne również wydaje się odniesienie do przypadku Gruzji refleksji René Girarda, że religia, oferując pokój, korzeniami sięga jednak przemocy ${ }^{162}$. Religia w Gruzji inspiruje podmioty nacjonalistyczne i wspiera nacjonalizm.

159 P. Michel, Polityka i religia. Wielka przemiana, tłum. B. Czarnomska, Kraków 2000, s. 84-85.

160 R. Król-Mazur, op. cit., s. 281-303; S. Dundua, Religious Factors in Georgian Politics (the 2008 General Elections), „Central Asia and the Caucasus” 1 (2010), s. 173-180; B. Chedia, The Georgian Orthodox Church in Current Georgian policy, „Central Asia and the Caucasus” 4-5 (58-59) (2009), s. 169-175.

161 Zaangażowanie duchownych na rzecz przezwyciężania konfliktów etnicznych i etnoreligijnych określane mianem faith-based diplomacy przybiera również postać instytucjonalną zarówno na poziomie krajowym (np. różnego rodzaju rady, w skład których wchodzą przedstawiciele różnych Kościołów), jak i międzynarodowym.

162 R. Girard, Sacrum i przemoc, tłum. M. i J. Plecińscy, Poznań 1993. 


\section{The role of Georgian Autocephalous Orthodox Church in South Caucasus conflicts}

\section{Abstract}

The dissertation focuses on mutual ties and relations between the Church and the authorities and politics in Georgia. National identity of Georgians is strongly connected with Christianity and separate ecclesiastical structures. A long tradition of autocephaly and differences resulting from autonomous development created a specific feeling of attachment to the Church, which Georgians expressed in the opposition to subordinate their Church to Russian Orthodox Church, the Russian Empire, and the Soviet power. The position of Georgian Autocephalous Orthodox Church in the country's life after the fall of the communism was shaped by the political situation of that period. The role of the national church was strongly emphasized and freedom regaining Georgians combined national slogans with their religious orientation. For a long time Georgian Church was the only one allowed to function in Georgia. The authorities, in need of the support of the Church, decided to give it an exceptional role in the state (Art. 9 of 1995 Constitution and the "Constitution Agreement" executed and ratified in October 2002 by the parliament and the Holy Synod). These and other provisions included in the legal acts resulted in a tremendous preference of Georgian Church which leads to spreading of the religious extremism in the country, initially tolerated by the authorities. However, with the demands to introduce political reforms aimed at bringing Georgia closer to the model of Western countries and the country's aspiration to join the European Union the authorities were compelled to take steps and decisions which were contrary to the standpoint and activity of Georgian Church. This, however, for long time enjoying incredible social trust, managed to maintain its position, among the others due to the ability to skilfully balance between the expectations and needs of the authorities and the accomplishment of own goals. Georgian Church is considered one of the most important actors in the Georgian public life and its influence on politics is considerable. It plays a significant role both in exacerbating ethnic, religious, and social conflicts in Georgia which translates into the relations of the country with her neighbours and the mitigation of emerging problems (after the Georgian-Ossetian-Russian war Georgian Church is the sole representative of the State in relations with the Russian Federation.

\section{Роль Грузинской Апостольской Автокефальной Православной Церкви в конфликтах на Южном Кавказе}

\section{Аннотация}

Задачей статьи является приблизить вопросы, связанные с присутствием христианства на территории Грузии и показать насколько большую роль играет Грузинская Апостольская Автокефальная Православная Церковь в истории грузинского народа. Национальная идентичность грузин сильно связана с христианством и отдельными церковными структурами, что существенно влияет на отношения с негрузинскими общинами (на Южном Кавказе - Грузия - страна с самым большим процентом этнических меньшинств), много поколений живущими в Грузии и владеющими местным языком, но к которым относятся как к «чужим» из-за «негрузинской» конфессии

Новые власти (после обретения Грузией независимости в 1991 г.) обеспечили исключительную роль в государстве Грузинской Апостольской Автокефальной Православной Церкви посредством соответствующего законодательства. Это способствовало обострению отношений с национальными и конфессиональными меньшинствами, а также, в большой степени, усилению социальной напряженности и отразилось также на 
отношениях Грузии с ближайшими соседями. Именно эти аспекты автор подробно рассматривает в представленном тексте и показывает, как в результате специфических отношений, которые образовались в Грузии между церковью и государством, религия была подвержена инструментализации и использована для достижения текущих политических целей. В заключение статьи утверждается, что религия в Грузии вдохновляет националистические субъекты и поддерживает национализм.

\section{Bibliografia}

\section{Źródła:}

Porozumienie Konstytucyjne między Państwem Gruzińskim i Gruzińskim Apostolskim Autokefalicznym Kościołem Prawosławnym z 14 X 2002, w: Badania wschodnie. Polityka wewnętrzna i międzynarodowa, red. W. Baluk, Z.J. Winnicki, Wrocław 2008

The Constitution of the Republic of Georgia, Parliament of Georgia, http:// www.parliament.ge/ files/68_1944_951190_CONSTIT_27_12.06.pdf

\section{Opracowania:}

Baramidze R., Islam in Adjara - Comparative Analysis of Two Communities in Adjara, w: Changing identities: Armenia, Azerbaijan, Georgia. Collection of Selected Works (ed.) V. Voronkov, Tbilisi 2011

Chmielowski T.T., Kościół Prawosławny w Gruzji w latach zaboru rosyjskiego i władzy sowieckiej (XIX-XX w.), „Archiwa, Biblioteki i Muzea Kościelne” 1998, nr 70

Corm G., Religia i polityka w XXI wieku, tłum. E. Cylwik, Warszawa 2007

Curanović A., Kontrolowana „zemsta Boga”: znaki szczególne poradzieckiego systemu wyznaniowego, w: Religia i polityka na obszarze Europy Wschodniej, Kaukazu i Azji Centralnej, red. T. Stępniewski, Lublin-Warszawa 2013

Curanović A., Religie, Kościoły i konflikty międzywyznaniowe w regionie Kaukazu, w: Wprowadzenie do Studiów Wschodnioeuropejskich, t. 4: Armenia, Azerbejdżan, Gruzja. Przeszłość i teraźniejszość, red. nauk. M. Korzeniowski, D. Tarasiuk, K. Latawiec, Lublin 2013

Curanović A., Rosyjsko-kaukaskie sąsiedztwo w kontekście stosunków międzywyznaniowych, w: Kaukaz w stosunkach międzynarodowych. Przeszłość, teraźniejszość, przyszłość, red. P. Olszewski, K. Borkowski, Piotrków Trybunalski 2008

Chedia B., The Georgian Orthodox Church in Current Georgian policy, „Central Asia and the Caucasus" 4-5 (58-59) (2009)

Domagała M., Percepcja konfliktu kaukaskiego w polskich mediach w 2008 r., Warszawa 2014

Dundua S., Religious Factors in Georgian Politics (the 2008 General Elections), „Central Asia and the Caucasus" 1 (2010)

Fox J., Sandler S., Bringing Religion into International Relations, New York 2004.

Furier A., Droga Gruzji do niepodległości, Poznań 2009

Furier A., Znaczenie relacji między Kościołem a władzami państwowymi dla kształtowania się państwa i narodu gruzińskiego, w: Etniczność a religia, red. A. Posern-Zieliński, Poznań 2003

Girard R., Sacrum i przemoc, tłum. M. i J. Plecińscy, Poznań 1993

Gruzja między Wschodem a Zachodem, red. K. Masiuk et al., Kraków-Warszawa 2012

Hewitt G., Discordant Neighbours: A Reassessment of the Georgian-Abkhazian and Georgian-South Ossetian Conflicts, Leiden 2013

Kakachia K., Is Georgia's Orthodox Church an Obstacle to European Values? PONARS Eurasia Policy Memo No. 322 June 2014, http://www.ponarseurasia.com/sites/default/files/policy-memos-pdf/Pepm_332_Kakachia\%20_June\%202014.pdf (dostęp: 20.05.2015) 
Komoszyńska I., Niektóre aspekty współczesnych antagonizmów gruzińsko-ormiańskich, w: Dylematy kaukaskie. Problemy narodowościowe i migracyjne, red. M. Ząbek, Warszawa 2010

Kończak L., Religia i konflikty religijne w niepodległej Gruzji, w: Konflikty na obszarze byłego ZSRR, red. P. Adamczewski, Poznań 2009

Król-Mazur R., Polityczne aspekty działalności Prawosławnego Autokefalicznego Apostolskiego Kościoła Gruzińskiego po 1991 r. w: Na wschód od linii Curzona. Ksiegga Jubileuszowa dedykowana profesorowi Mieczysławowi Smoleniowi, red. R. Król-Mazur, M. Lubina, Kraków 2014

Kuca G., Grzybowski M., System konstytucyjny Gruzji, Warszawa 2012

Laboa J.M., Monastycyzm gruziński, w: Mnisi Wschodu i Zachodu. Historia monastycyzmu chrześcijańskiego, red. J.M. Laboa, Warszawa 2009

Legucka A., Geopolityczne uwarunkowania i konsekwencje konfliktów zbrojnych na obszarze poradzieckim, Warszawa 2013

Leszczenko L., Instytucja ombudsmana w państwach poradzieckich. Geneza - status prawny rozwój, Warszawa 2011

Marczewska-Rytko M., Religia i polityka w globalizującym się świecie, Lublin 2010.

Mariański J., Globalizacja i Kościoły - sprzymierzeńcy czy konkurenci, w: Religia i religijność $w$ warunkach globalizacji, red. M. Libiszowska-Żółtkowska, Kraków 2007

Marjanli M., Armenians. Russia. The Caucasus, Dubai 2011

Marsagiszwili M., Działalność Departamentu Policji Patrolowej Gruzji. Prawa Człowieka, w: Polsko-gruzińska wymiana doświadczeń w zakresie podejmowania czynności stużbowych przez funkcjonariuszy policji $w$ aspekcie praw $i$ wolności człowieka, red. I. Nowicka, T. Mosio, Szczytno 2008

Materski W., Gruzja, Warszawa 2010

Matiunin S., Konflikty religijne na terenie byłego ZSRR, w: Religie i kościoły w społeczeństwach postkomunistycznych, red. I. Borowik, A. Szyjewski, Kraków 1993

McGuire M.B., Religia w kontekście społecznym, tłum. S. Burdziej, Kraków 2012

Modebadze V., Historical Background of Meskhetian Turks' Problem and Major Obstacles to the Repatriation Process, „IBSU Scientific Journal” 3(1) (2009

Nieczuja-Ostrowski P., Religia w polityce w państwach Kaukazu Południowego, w: Religia i polityka na obszarze Europy Wschodniej, Kaukazu i Azji Centralnej, red. T. Stępniewski, LublinWarszawa 2013

Parzymies D., Życie codzienne w Tbilisi 1999-2003, Warszawa 2004

Pataraia T., Rozwój polityki migracyjnej w Gruzji, w: Polityka migracyjna Gruzji: wnioski z polskich doświadczeń, red. P. Kaźmierkiewicz, T. Pataraia, Warszawa 2011

Peradze G., Kościół Gruziński pod bolszewizmem w: idem, Dzieła zebrane, t. 2, red. ks. H. Paprocki, Warszawa 2011

Peradze G., Problemy historii początków Kościoła Gruzińskiego w: idem, Dzieła zebrane, t. 2, red. ks. H. Paprocki, Warszawa 2011

Prześlakiewicz P., Pamięć polskości w południowej Gruzji, w: Etnos przebudzony, red. L. Mróz, Warszawa 2004

Rtskhiladze G., Religion and Conflict Potential in Georgia, „Central Asia and the Caucasus” 3 (39) (2005)

Sabanadze N., Globalization and Nationalism: the Cases of Georgia and the Basque Country, Budapest-New York 2010, http://books.openedition.org/ceup/573 (dostęp: 1.07.2015)

Suny R.G., The Making of Georgian Nation, Bloomington 1994

Szabaciuk A., Między konfliktem a pokojem. Polityka etniczna $i$ wyznaniowa Gruzji w latach 1991-2012, „Wschodnioznawstwo” 2012

Szyszlak T.J., Próby teoretycznego ujęcia postradzieckich konfliktów religijnych, w: Religia i polityka na obszarze Europy Wschodniej, Kaukazu i Azji Centralnej, red. T. Stępniewski, LublinWarszawa 2013

Szyszlak T.J., Stosunki państwa z Apostolskim Autokefalicznym Kościołem Prawosławnym we współczesnej Gruzji, w: Badania wschodnie. Polityka wewnętrzna i międzynarodowa, red. W. Baluk, Z.J. Winnicki, Wrocław 2008 
Szyszlak T.J., Wolność religijna w konstytucjach i ustawach wyznaniowych państw postradzieckich, „Studia z prawa wyznaniowego" 10 (2007)

The Political Landscape of Georgia. Political Parties: Achievements, Challenges and Prospects, eds. G. Nodia, Á. Pinto Scholtbach, Delft 2006

Trier T., Tarkhan-Mouravi G., Kilimnik F., Meskhetian: Homeward Bound, Tbilisi 2011

Wojtasiewicz W., Polityka zagraniczna Republiki Gruzji pod rząami premiera Bidziny Iwaniszwilego - kontynuacja czy zmiana?, w: Prawo i polityka na wschód od Europy, red. J. Marszałek-Kawa, P. Wawrzyński, Torun 2014

Zadura D., Chrześcijaństwo i Kościół narodowy w historii Gruzji - od źródeł do okresu sowieckiego, „Pro Georgia. Journal of Kartvelological studies” 19 (2009)

Zadura D., Naród w tygrysiej skórze. Tożsamość narodowa Gruzinów w dobie „rewolucji róż”, w: Dylematy kaukaskie. Problemy narodowościowe i migracyjne, red. M. Ząbek, Warszawa 2010

Zajączkowski W., Rosja i narody. Ósmy kontynent - szkic z dziejów Eurazji, Warszawa 2009.

Zasztow K., Georgia Dream's Foreign Policie: An Attempt to Change the Paradigm?, „The Polish Institute of International Affairs Policy Paper" 3(51) (2013)

Zenderowski R., Religia a tożsamość narodowa i nacjonalizm w Europie Środkowo-Wschodniej. Między etnicyzacja religii a sakralizacją etnosu (narodu), Wrocław 2011

Гаджиев К.С., Кавказский узел в геополитических приоритетах России, Москва 2010.

Рамишвили В., Армяно-Грузинский спор: Джавахети или Джавахк?, „КАВКАЗ \& ГЛОБАЛИЗАЦИЯ” „Журнал социально-политических и экономических исследований” 5 (2007), http://www.ca-c.org/c-g/2007/journal_rus/c-g-4/02.shtml (dostęp: 1.07.2015)

Силантьев Р., Религиозный фактор во внешнеполитических конфликтах на Кавказе, w: Религия и конфликт, ред. А. Малашенко, С. Филатов, Москва 2007

Токарев А., Влияние государственности на эволюичю политических режимов Грузии и Украины в 1991-2014 годах, Москва 2015

\section{Analizy i raporty oraz zasoby internetowe:}

Cerkiew protestuje przeciwko nowemu prawu, http://www.kaukaz.info/cerkiew-protestuje-przeciwko-nowemu-prawu.html (dostęp: 29.06.2014)

Chanadiri A., Gruzini. Zagubieni Europejczycy, 14.12.2013, http://zw.lt/opinie/gruzini-zagubieni-europejczyzy/ (dostęp: 9.07.2015)

Ćwiek-Karpowicz J., Cerkiew prawosławna w polityce zagranicznej Rosji, Biuletyn PISM, 9.08.2010, nr 110 (718), s. 2281, http://www.pism.pl/zalaczniki/Biuletyn_718_3.pdf. (dostęp: 20.07.2015)

Do Rosji przybywa Katolikos-Patriarcha Gruzji Eliasz II, 20.01.2013, http://polish.ruvr.ru/2013_ 01_21/Do_Rosji_przybywa_Katolikos_Patriarcha_Gruzji_Eliasz_II (dostęp: 22.07.2015)

Dyskryminacja ateistów w Gruzji. Wpływy Cerkwi w interesie Rosji, 21.07.2015 http://onet.tv/i/ dowiedzsie/dyskryminacja-ateistow-w-gruzji-wplywy-cerkwi-w-interesie-rosji/3zdzlh (dostęp: 22.07.2015)

Dzieduszycka-Manikowska A., Dramat kościoła na Kaukazie, PCh24.pl, 4.08.2013, http://www. pch24.pl/Mobile/Informacje/informacja/id/16759 (dostęp: 12.08.2015).

Eliasz II Patriarcha Gruzji, http://edu.gazeta.pl/edu/h/Eliasz+II+\%28patriarch+Gruzja\%29\#Dzia. C5.82alno.C5.9B.C4.87_w_Gruzji (dostęp: 22.06.2015)

Falkowski M., Gruzja: kryzys polityczny i rosyjskie zagrożenie, Analizy Ośrodka Studiów Wschodnich, http://www.osw.waw.pl/pl/publikacje/analizy/2014-11-19/gruzja-kryzys-polityczny-i-rosyjskie-zagrozenie (dostęp: 10.06.2015)

Georgia 2013 International Religious Freedom Report, Department of State USA, 28.07.2014, www.state.gov/documents/organization/222429.pdf (dostęp: 15.07.2015)

Gruzin nie może być katolikiem, „Niedziela”, 11.06.2008, www.niedziela.pl/wiad.php?p= 200806\&idw=149 
Gruzińska Cerkiew krytykuje nowe przepisy, http://wiadomosci.wp.pl/kat,1356,title,GruzinskaCerkiew-krytykuje-nowe-przepisy,wid,13573623, wiadomosc.html?ticaid=112548 (dostęp: 20.07.2015)

Gruzja: władze zamierzaja finansować Kościót katolicki, „Niedziela”, 27.01.2014, http://www. niedziela.pl/artykul/7723/Gruzja-wladze-zamierzaja-finansowac (dostęp: 22.06.2015)

Human Rights World Report 2014: Georgia, http://www.hrw.org/world-report/2014/country-chapters/georgia

Matusiak M., Wzrost nastrojów konserwatywno-nacjonalistycznych?, Ośrodek Studiów Wschodnich, 4.09.2013, http://www.osw.waw.pl/publikacje/analizy/2013_09_04/gruzja-wzrostnastrojow-konserwatywno-nacjonalistycznych (dostęp: 4.06.2015)

Moscow Patriarchate shall not encourage the separation of the Abkhaz Diocese from Georgian Church, 16.09.2009, http://www.interfax-religion.com/?act=news\&div=6445 (dostęp: 22.06.2015)

Ormianie w Gruzji, http://www.fundacjaormiańska.pl/ormianie-w-gruzji/ (dostęp: 20.07.2015)

Patriarch Ilia II asking Turkish authorities to resume services at Georgian churches, Tbilisi 13.09.2014, http://www.pravoslavie.ru/english/73691.htm (dostęp: 20.06.2015)

Public Attitudes in Georgia: Results of an apr 2014 Survey, http://www.ndi.org/files/Georgia-April14-Survey-Political-English.pdf (dostęp: 20.06.2015)

Rada Europy o problemach mniejszości etnicznych i religijnych w Gruzji, Ośrodek Studiów Wschodnich, 12.10.2009, http://www.osw.waw.pl/pl//publikacje/tydzień-na-wschodzie/2009-10-12/rada-europy-o-problemach-mniejszosci-etnicznych-i-religijnych-w-Gruzji (dostęp: 13.04.2015)

Szef watykańskiej dyplomacji oburzony postawa Gruzji, Katolicka Agencja Informacyjna (KAI), 21.09.2003, http://ekai.pl/wydarzenia/x5651/szef-watykanskiej-dyplomacji-oburzonypostawa-gruzji (dostęp: 25.06.2015)

Tauber M., Geopolityka, sytuacja wewnętrzna w Gruzji, a stanowisko Gruzińskiej Cerkwi Prawosławnej, 22.04.2013, www.forum-ekonomiczne.pl/article/geopolityka-sytuacja-wewnętrzna-w-gruzji-a-stanowisko-gruzinskiej-cerkwi-prawoslawnej/\# (dostęp: 12 I 2015)

The Georgian Authorities should not water down the country's first anti-discrimination bill, Amnesty International Public Statement, 24.04.2014, https://www.amnesty.org/en/documents/eur56/001/2014/en/ (dostęp: 20.05.2015)

Rosyjsko-gruziński konflikt prawosławny, Radio Watykańskie, 27.09.2010, http://www.deon.pl/ religia/kosciol-i-swiat/z-zycia-kosciola/art,3191,rosyjsko-gruzinski-konflikt-prawoslawny. html (dostęp: 16.05.2015)

Wojtasiewicz W., „Wojna religijna” i afera szpiegowska $w$ Gruzji, Nowa Europa Wschodnia (NEW), 18.07.2011, www.new.org.pl/2011-07-18,wojna_religijna_i_afera_szpiegowska_w_ gruzji.html (dostęp: 20.07.2014).

Wojtasiewicz W., Wybory za pasem, Nowa Europa Wschodnia (NEW), 4.04.2013, www.new. org.pl/2013-04-04,wybory_za_pasem.html (dostęp: 5.06.2015)

Zadura D., Liberalna demokracja $i$ prawosławny dżihad w Gruzji, 21.09.2010, www.psz. pltekst-33917/Liberalna-demokracja-i-prawoslawny-dzihad-w-Gruzji (dostęp: 20.06.2015)

Zadura D., Ormiańskie świątynie w Tbilisi, http:// www.kaukaz.net/cgi-bin/blosxom.cgi/polish/ gruzja/gruzja_ormianskie_koscioly (dostęp: 14.06.2015)

Абрамян Г., Армения: Имущественные споры способствуют эскалации напряженности между церквями Армении и Грузии, 11.08.2011, Eurasianet.org, http://russian.eurasianet. org/node/58814 (dostęp: 20.06.2015)

В населенном армянами Самихе-Джавахети поднят вопрос об автономии в составе Грузии, REGNUM -Информационное агентство, 22.08.2008, http://www.regnum.ru/ news/1043811.html\#ixzz29rSJzn8C (dostęp: 27.08.2015)

Государство и Церковь в Грузии будут вместе сохранять культурное наследие, Образованне и Православие, 20.07.2014, http://www.orthedu.ru/hppc/news-hppc/10797gosudarstvo-i-cerkov-v-gruzii-budut-vmeste-sohranyat.html (dostęp: 20.05.2015) 
Грузия ведет переговоры с Азербайджаном о передаче монастыря Удабно входяего в комплекс Давид Гареджи, Православие.Ru, 15.05.2012, http://www.pravoslavie.ru/news/53516. htm (dostęp: 16.06.2015)

Грузия вошла в десятку самых религиозных стран, Православие.Ru, 14.04.2015, http:// www.pravoslavie.ru/news/78649.htm (dostęp 15.05.2015)

Грузия профинансирует Грузинскую Православную Церковь в размере 25 миллионов лари, Православие.Ru, 8.10.2013, http://www.pravoslavie.ru/news/64750.htm (dostęp: 16.05.2015).

Двали Г., Грузия отделилась от иеркви, „Коммерсанть”, 7.07.2011

Илия II попросил Иран не наказывать грузин, возвращающцихся в Христианство, 21.08.2013, Образование и Православие, http://www.orthedu.ru/news/7731-iliya-ii-poprosil-iranne-nakazyvat-gruzin-vozvrashhayushhixsya-v-xristianstvo.html (dostęp: 25.06.2015)

Комплекс Давид Гареджи является клтурным памятником Грузии - Грузинский МИД, Православие. Ru. 16.05.2012, http://www.pravoslavie.ru/news/53559.htm (dostęp: 16.06.2015)

Корсо М., Грузия: Православная иерковь может превратиться в очаг нетерпимости?, 26.06.2013, Eurasianet.org, https://russian.eurasianet.org/node/60169 (dostęp: 20.06.2015)

Корсо М., Грузия: Растёт дискриминация в отношении мусульман?, 7.09.2013, Eurasianet. org, http://russian.eurasianet.org/node/60279 (dostęp: 20.06.2015)

Мальцев В., Илия II: „Не унижайте Церковь!” Масштабные протесты православных верующих заставили власти Грузии свернуть с европейского пути, http://www.religare. ru/2_87652.html (dostęp: 26.06.2015)

Московский Патриархат принимает делегацию Грузинской Православной Церкви, 13.02.2014, Образование и Православие, http://www.orthedu.ru/newОбразование и Православиеs/9388-14.html (dostęp: 25.06.2015)

Обнародовано постановление Священного Синода Грузинской Православной Церкви, 6.06.2014, Образование и Православие, http://www.orthedu.ru/hppc/news-hppc/1044814.html (dostęp: 25.06.2015)

Патриархи Грузии: Продажа земли иностраицам ставит под удар сущетвование государста, Православие.Ru, 14.07.2014, http://www.pravoslavie.ru/news/71975.htm (dostęp: 16.05.2015)

Патриарх Илия II: были братьями и останемся братьями, 10.08.2013, Образование и Православие, http://www.orthedu.ru/news/7667-patriarx-iliya-ii-byli-bratyami-iostanemsya-bratyami.html (dostęp: 26.06.2015)

Премьер - министр Грузии: Вся наша история зиждется на христянской вере, Православие.Ru. 15.05.2014, http://www.pravoslavie.ru/news/70715.htm (dostęp: 16.05.2015)

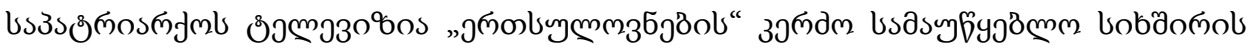
zsonoة3ol zsдm, 14.06.2013, http://www.patriarchate.ge/?action=news_show\&mode=news\&id=765. (dostęp: 4.06.2015)

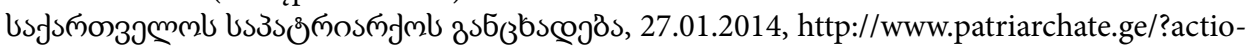
$\mathrm{n}=$ news_show\&mode $=$ news\&id=789 (dostęp: 22.06 .2015$)$

Renata Król-Mazur, dr, adiunkt w Instytucie Nauk Politycznych i Stosunków Międzynarodowych Uniwersytetu Jagiellońskiego; zainteresowania badawcze: historia nowożytna i współczesna, zwłaszcza zagadnienia związane z historią Polski, Ukrainy, Rosji, Armenii, dziejami Kaukazu oraz problematyka mniejszości narodowych, etnicznych i religijnych, wojskowości oraz polskiej myśli politycznej; współpracuje z organizacjami mniejszości ormiańskiej w Polsce (reniakrol@poczta.onet.pl). 